Mississippi College School of Law

MC Law Digital Commons

Journal Articles

Faculty Publications

2015

\title{
Anticipating a Sea Change for Insider Trading Law: From Trading Plan Crisis to Rational Reform
}

John P. Anderson

Mississippi College School of Law, jpanders@mc.edu

Follow this and additional works at: http://dc.law.mc.edu/faculty-journals

Part of the Securities Law Commons

\section{Recommended Citation}

2015 Utah L. Rev. 339 (2015).

This Article is brought to you for free and open access by the Faculty Publications at MC Law Digital Commons. It has been accepted for inclusion in Journal Articles by an authorized administrator of MC Law Digital Commons. For more information, please contact walter@mc.edu. 


\title{
ANTICIPATING A SEA ChANGE FOR INSIDER TRADING LAW: From Trading Plan CRISIS TO Rational REFORM
}

\author{
John P. Anderson ${ }^{*}$
}

\section{Abstract}

The Securities and Exchange Commission is poised to take action in the face of compelling evidence that corporate insiders are availing themselves of rule-sanctioned Trading Plans to beat the market. These Trading Plans allow insiders to trade while aware of material nonpublic information. Since the market advantage insiders have enjoyed from Plan trading can be traced to loopholes in the current regulatory scheme, increased enforcement of the existing rules cannot address the issue. But, simply tweaking the existing rule structure to close these loopholes would not work either. This is because the SEC adopted the current rule as a part of a delicate compromise with the courts in the "use versus possession" debate over the proper test of scienter for insider trading liability. The current rule reflects the SEC's preferred test (mere "awareness"), but it provides for Trading Plans as an affirmative defense in order to pass judicial scrutiny. Thus, any attempt to simply close the loopholes in Trading Plans while maintaining the awareness test would upset this delicate compromise. Only a comprehensive change to the current insider trading enforcement regime can address the issue.

The reform proposed here begins with the recognition that Plan trading is generally done with the firm's awareness and consent. Such trading is therefore a form of issuer-licensed insider trading. Since there are strong arguments that there is no moral wrong or economic harm done by issuer-licensed insider trading, the regulatory regime should openly embrace it as a permissible form of compensation through firm-sanctioned Modified Trading Plans, so long as there is adequate disclosure. Though such liberalization would represent a radical departure from the current enforcement regime, it would be within the SEC's rulemaking authority, and would be consistent with Supreme Court precedent. Most importantly,

* (C) 2015 John P. Anderson. Associate Professor, Mississippi College School of Law. Many thanks to Professors Miriam Baer, Jill Fisch, Joan Heminway, Gerry Moohr, Donna Nagy, Ellen Podgor, Elizabeth Pollman, and Charles Pouncy for their helpful input on an early draft of this paper during our Insider Trading Discussion Group at the 2013 Southeastern Association of Law Schools Annual Meeting. I offer a special thanks to Professor Jeanne Schroeder for her detailed comments and suggestions, which have improved the Article immensely. I would also like to thank my research assistants, Walker Moller and Katie Sanders, for their excellent work on this project. Finally, I thank Mississippi College School of Law for the financial support provided for this project. 
it would dramatically improve the current enforcement regime in terms of justice, clarity, efficiency, and coherence.

It is sometimes said there is nothing like a good crisis for effecting much needed change. The current media attention and public scrutiny over corporate insiders' exploitation of rule-sanctioned Trading Plans may be just the crisis to spur the SEC to adopt a more rational and just approach to insider trading enforcement. The outline for such reform is proposed here.

\section{INTRODUCTION}

In December 2012, the Manhattan office for the United States Attorney launched a criminal investigation into whether corporate executives from seven different companies violated insider trading laws by improperly trading in shares of their own company's stock.' In an 'era of unprecedented insider-trading prosecutions," "2 this investigation (and others initiated since ${ }^{3}$ ) represents a shift in focus by prosecutors and regulators from the aggressive prosecution of trading on material nonpublic information by tippees and misappropriators to true corporate insiders. ${ }^{4}$ The change in emphasis is a reaction to mounting public pressure in light of a recent series of academic studies ${ }^{5}$ and Wall Street Journal articles ${ }^{6}$ raising the

${ }^{1}$ See Susan Pulliam et al., Insider-Trading Probe Widens-U.S. Launches Criminal Investigation into Stock Sales by Company Executives, WALL ST. J., Dec. 11, 2012, at A1.

2 Jenny Strasburg \& James Sterngold, SAC Hit with Criminal Case-Prosecutor Calls Hedge Fund 'Magnet for Market Cheaters'; Firm Denies Wrongdoing, WALL ST. J., July 26, 2013, at Al.

${ }^{3}$ See Susan Pulliam et al., Insider-Trading Probe Trains Lens on Boards, W ALL ST. J. (Apr. 30, 2013, 12:07 AM), http://online.wsj.com/articles/SB100014241278873237981045 78453260765642292, archived at http://perma.cc/F9D7-LJVH (discussing various investigations brought since December 2012).

${ }^{4}$ See Pulliam et al., supra note 1 , at A1.

5 See, e.g., Alan D. Jagolinzer, SEC Rule 10b5-1 and Insiders' Strategic Trade, 55 MGMT. SCI. 224, 226 (2009) (describing an academic study that "examines whether insiders strategically trade within the safe harbor").

6 See Rob Barry et al., Big Sales by Big Lots Brass-Executives' Stock Moves Netted $\$ 23$ Million Ahead of Bad News in April, WALL ST. J. (Dec. 11, 2012, 7:18 PM), http://www.wsj.com/articles/SB10001424127887324339204578173680170444970,

archived at http://perma.cc/FK3L-AND5; Jean Eaglesham \& Rob Barry, Trading Plans Under Fire, WALL ST. J. (Dec. 13, 2012, 9:00 PM), http://online.wsj.com/articles/SB10001 424127887324296604578177734024394950, archived at http://perma.cc/4EC6-CJF5; Pulliam et al., supra note 3; Pulliam et al., supra note 1, at A1; Susan Pulliam \& Rob Barry, Directors Take Shelter in Trading Plans, WALl St. J., Apr. 25, 2013, at Al [hereinafter Pulliam \& Barry, Directors Take Shelter in Trading Plans]; Susan Pulliam \& Rob Barry, Executives' Good Luck in Trading Own Stock, WALl ST. J. (Nov. 27, 2012, 11:17 PM), http://www.wsj.com/articles/SB10000872396390444100404577641463717344178, archived at http://perma.cc/QE56-AH8Y [hereinafter Pulliam \& Barry, Executives' Good Luck]; Susan Pulliam \& Rob Barry, Executives Sold Amid Stock Buyback-Such 
concern that corporate executives are gaining an unfair advantage over the market by exploiting "loopholes"7 or ambiguities" in what are commonly referred to as 10b5-1 trading plans.

The Securities and Exchange Commission ("SEC") adopted Exchange Act Rule $10 \mathrm{~b} 5-1^{9}$ in 2000 as part of an attempt to clarify the elements of, and defenses to, insider trading liability under SEC Rule 10b-5. ${ }^{10}$ Among other things, Rule 10b51 offers corporate executives an affirmative defense against the charge that they violated insider trading laws when they buy or sell shares in their company's stock as part of a written plan ("Trading Plan" or "Plan") entered into when the insider was not aware of material nonpublic information. ${ }^{11}$ This defense is available even if the insider later becomes aware of material nonpublic information at the time the Plan trades are executed. ${ }^{12}$

Transactions, Considered Red Flags to Investors, Raised Concerns Among Employees at Firm, Wall ST. J., Dec. 21, 2012, at C1; Susan Pulliam \& Rob Barry, Investors Call for More Disclosure of Executive Trades, WALL ST. J. (Nov. 29, 2012, 12:07 PM), http://www.wsj.com/articles/SB10001424127887324020804578147193237802774,

archived at http://perma.cc/MC65-F9PN [hereinafter Pulliam \& Barry, Investors Call for More Disclosure]; Susan Pulliam \& Rob Barry, Trading Focus Is Pushed, Wall ST. J., Jan. 24, 2013, at C1; Michael Siconolfi, Pension Funds Seek Insider Curbs, Wall ST. J. (Dec. 31, 2012, 8:01 PM) http://online.wsj.com/articles/SB1000142412788732363550457821178 1992442110, archived at http://perma.cc/HR6G-PRMU; Michael Siconolfi \& Jean Eaglesham, SEC Is Pressed to Revamp Executive Trading Plans, WALL ST. J. (May 9, 2013, 8:54 PM), http://online.wsj.com/articles/SB10001424127887324059704578473382576553 460, archived at $\mathrm{http}: / /$ perma.cc/T9JM-XXMG.

This recent series of articles was preceded by intermittent treatment of 10b5-1 trading plans by the Wall Street Journal after Rule 10b5-1 was adopted in 2000. See Matt Andrejczak, Mattel's Chief Sells Near Highs Via Prearranged Trading Plan, WALL ST. J., Apr. 30, 2008, at C18; Tony Cooke, Director's Trade Plan Shields Against 'Insider' Suspicion, WALL ST. J., June 18, 2003, at C15; Tony Cooke \& Serena Ng, Insiders Prosper Despite SEC Rule, WALL ST. J. (Aug. 5, 2005, 12:01 AM), http://online.wsj.com/news/ articles/SB112320798601405793, archived at http://perma.cc/78TK-D3FV; David J. Reynolds, Reddy Ice Executives Gain on Prearranged Trading Plans, WALL St. J., Dec. 10, 2008, at C7; Dionne Searcey \& Kara Scannell, SEC Now Takes a Hard Look at Insiders' 'Regular' Sales, WALL St. J., Apr. 4, 2007, at C1; Ed Welsch, Trading Plans Offer a Good Che to Sell; Aggressive 10b5-1s Especially Predict Underperformance, WALL ST. J., Apr. 9,2008 , at $\mathrm{C} 4$.

${ }^{7}$ See, e.g., Eaglesham \& Barry, supra note 6 (explaining the existing loopholes).

${ }^{8}$ Pulliam \& Barry, Directors Take Shelter in Trading Plans, supra note 6, at A1.

${ }^{9} 17$ C.F.R. $\S 240.10 \mathrm{~b} 5-1$ (2014).

${ }^{10}$ See Selective Disclosure and Insider Trading: Final Rule, 65 Fed. Reg. 51,716 (Aug. 24, 2000) (to be codified at 17 C.F.R. pts. 240, 243, 249) [hereinafter August 2000 Exchange Act Release].

1117 C.F.R. $\$ 240.10 b 5-1$ (c) (2014). Rule 10b5-1(c)(1)(i)(B) lays out the specific requirements a plan must satisfy. Part II of this Article will explain the requirements of Rule 10b5-1 more fully.

${ }^{12}$ August 2000 Exchange Act Release, supra note 10, at 51,716 (explaining that the affirmative defense is available to insiders who trade under a 10b5-1 plan while aware of 
Despite the fact that Rule 10b5-1 precludes insiders from entering into a Trading Plan while aware of material nonpublic information, multiple studies indicate that insiders trading through these Plans manage to significantly outperform the market. ${ }^{13}$ These studies, along with recent press highlighting examples of suspiciously timely trades by company executives, have led investors, former regulators, and academics to conclude that, contrary to the SEC's intentions for the rule, it has been a "huge gift to insiders ...."14 Insiders are using these Trading Plans as a "tool" for trading on material nonpublic information while avoiding civil or criminal liability. ${ }^{15}$

The concern that Rule 10b5-1 has become a de facto safe harbor for insiders trading on material nonpublic information has spurred public demands for the SEC to take action. Thomas Kim, former chief counsel of the SEC's Division of Corporation Finance, responded to media reports of Trading Plan abuse, stating that the SEC would "love to catch" a high-ranking corporate executive abusing the Trading Plans "and use him as an example."16 According to Kim, the SEC is "looking for big cases to send a message." enough. Citing the recent Wall Street Journal articles, the Council of Institutional Investors ("CII"), a nonpartisan association of public, corporate, and union pension funds with assets of more than three trillion dollars, sent a December 2012 letter to the SEC expressing the concern that "many executives at public companies have adopted practices with respect to Rule 10b5-1 plans that are inconsistent with the spirit, if not the letter of Rule 10b5-1."18 CII therefore requested that the SEC

material nonpublic information, so long as the insider was not aware of that information when entering into the plan).

${ }^{13}$ See, e.g., Pulliam \& Barry, Executives' Good Luck, supra note 6. The Wall Street Journal's own study reflects that among 20,237 of insiders "who traded their own company's stock during the week before their companies made news, 1,418 executives recorded average stock gains of $10 \%$ (or avoided $10 \%$ losses) within a week after their trades." Id. This was approximately double the number of those who had the stock "move against them that much." Id.; see also Jagolinzer, supra note 5, at 228-30 (noting that Plan 10b5-1 "sales transactions appear to follow systematic run-ups and precede systematic declines" while purchases "appear to precede systematic run-ups").

${ }^{14}$ Pulliam \& Barry, Investors Call for More Disclosure, supra note 6.

${ }^{15}$ Eaglesham \& Barry, supra note 6 ("Companies are using these plans as a tool . . that allows executives to do insider trading" (quoting Lisa Lindsley, a director at the American Federation of State, County and Municipal Employees Union)).

${ }^{16}$ Yin Wilczek, No Conclusion on 10b5-1 Plans, but SEC Monitoring Situation, Official Says, BLOOMBERG BNA (Apr. 18, 2013, 3:12 PM), https://www.bloomberglaw.com /s/news/2d7316f12bf2b30c45edb8a7e04297bl/document/MLHA5C3H65TU?headlineOnly $=$ false \&highlight $=$ Y in+Wilczek, archived at $\mathrm{https}: / /$ perma.cc/E9U9-JZND (quoting Thomas $\mathrm{Kim}$, former chief counsel of the SEC's Division of Corporation Finance).

${ }^{17}$ Id.

${ }^{18}$ Letter from Jeff Mahoney, Gen. Counsel, Council of Institutional Investors, to Elisse B. Walter, Chairman, U.S. Sec. \& Exch. Comm'n (Dec. 28, 2012) (discussing the potential misuse of Rule 10b5-1 Trading Plans for executive sales of company stock), available at http://www.cii.org/files/issues_and_advocacy/correspondence/2012/12_28_12_cii_letter_to 
"consider pursuing interpretive guidance or amendments to Rule 10b5-1" to close loopholes and foreclose the possibility of future abuse of Trading Plans by exploitation of ambiguities in the Rule. ${ }^{19}$

Whether or not the studies indicating insider exploitation of Trading Plans are accurate, perception is often all that matters to the financial markets. ${ }^{20}$ Moreover, the uncertainty generated by the confusion and vagueness in the current regulatory landscape is costly to firms, exposing all Plan trades (innocent and unethical alike) to suspicion ${ }^{21}$ and potential litigation. With such pressure mounting for change, it is almost certain the SEC will take some form of action in the near future. ${ }^{22}$

There are a number of reasons why an enduring solution to the problem of Trading Plans will not be simple to tailor within the existing insider trading enforcement framework. Since much of the problem stems from conduct that is actually permitted by the letter of the rule, mere interpretive guidance from the SEC would be inadequate, and attempts to discourage such trading by means of aggressive criminal prosecution would violate moral and constitutional principles. This leaves actual revision of the relevant statutes and/or rules as the only viable option. But Rule 10b5-1 was adopted to effect a delicate compromise between the SEC and the courts on the issue of whether actual "use" or mere "knowing possession" of material nonpublic information is necessary to establish liability for insider trading under Rule $10 \mathrm{~b}-5 .^{23}$ Since the affirmative defense for Plan trading was a crucial aspect of this compromise, nothing short of a significant departure from the current regulatory regime, a complete sea change, will be adequate to address the exploitation of Trading Plans. In anticipation of such a sea change in insider trading law, this Article suggests a path forward that, though representing a radical departure from the existing regime, would preserve its core concerns while improving it in terms of clarity, efficiency, and justice. A crucial premise of the proposed reform is that, at least in some circumstances, insider exploitation of Trading Plans may not be morally wrong or economically harmful.

sec_rule\%20_10b5-1_trading_plans.pdf, archived at http://perma.cc/3BMD-6EUM.

${ }^{19} I d$. When the SEC did not take immediate action, CII reiterated this request in a May 2013 letter. See Letter from Jeff Mahoney, Gen. Counsel, Council of Institutional Investors, to Mary Jo White, Chairman, U.S. Sec. \& Exch. Comm'n (May 9, 2013), available at http://www.cii.org/files/issues_and_advocacy/correspondence/2013/05_09_13_cii_letter_to _sec_rule_10b5-1_trading_plans.pdf, archived at http://perma.cc/ZQ59-4KTM.

${ }^{20}$ See Michael S. Melbinger, Rule 10b5-1Trading Plans Gain Attention in National Spotlight, 9 CCH EXECUTIVE COMPENSATION, no. 1, Mar. 20, 2013, available at $2013 \mathrm{WL}$ 5232111.

${ }^{21}$ See Pulliam \& Barry, Executives' Good Luck, supra note 6.

${ }^{22}$ See Eaglesham \& Barry, supra note 6.

${ }^{23}$ See August 2000 Exchange Act Release, supra note 10, at 51,716. 
Part II provides the historical background for Rule 10b5-1 Trading Plans. It begins with a summary of the insider trading regime under Section 10(b) of the Securities Exchange Act of $1934,{ }^{24}$ including the element of scienter which gave rise to the "use" versus "possession" debate that Rule 10b5-1 was intended to resolve. Part II closes by detailing the requirements of Rule 10b5-1 and the current understanding of Trading Plans under the rule.

Part III offers context for the current controversy by comparing the SEC's intended uses for Trading Plans with the reality of how they are being used by insiders and firms.

Part IV addresses the extent to which insiders' use of Trading Plans to gain a market advantage complies with current law. Although some uses of Trading Plans are clearly legal and some are clearly illegal, the legal status of a range of Plan trading remains unclear. Part IV closes by raising moral, constitutional, and economic concerns weighing in favor of broad reform in the midst of such uncertainty.

In anticipation of such reform, Part $V$ suggests that many of the simple revisions suggested by scholars, former regulators, and market participants would either fail to address the purported problem, or would undermine the delicate "use versus possession" compromise Rule 10b5-1 was designed to effect. Part V concludes by suggesting that nothing short of a complete overhaul of the existing regime will suffice to address the controversy.

Finally, Part VI outlines and defends the reform proposed here. This path to reform begins with the recognition that Plan trading is typically done with the firm's awareness and consent. Thus, even when based on material nonpublic information, such trading is a form of issuer-licensed insider trading. ${ }^{25}$ Since there are strong arguments that no moral or economic harm is done by issuer-licensed insider trading, such trading should be legalized as a permissible form of compensation, so long as it is regulated through a modified Trading Plan regime that requires disclosure. Though such liberalization would represent a radical departure from the current enforcement regime, it is consistent with precedent permitting persons to trade based on material nonpublic information in other circumstances and arguably coheres with the existing insider trading enforcement framework set out by the Supreme Court in United States v. O'Hagan. ${ }^{26}$ This proposed liberalization of insider trading law would be strictly limited to issuer-licensed insider trading through modified, firmsanctioned Trading Plans; it would not protect insiders who trade in violation of some promise or other commitment to their firms or those who trade on misappropriated information. And, of course, firms would be required to disclose their use of these modified Plans, as well as insiders' profits from their use. Part VI concludes by emphasizing the ways in which this liberalized insider trading regime

${ }^{24} 15$ U.S.C. $\S 78 \mathrm{j}(\mathrm{b})(2012)$.

${ }^{25}$ See John P. Anderson, Greed, Envy, and the Criminalization of Insider Trading, 2014 UTAH L. REV. 1, 28 (arguing that "nonpromissory insider trading"-here, "issuer-licensed insider trading"-is morally permissible).

${ }^{26} 521$ U.S. 642, 675-76 (1997). 
would offer an improvement over the existing regime in terms of clarity, efficiency, and justice.

\section{ORIGIN OF 10B5-1 AS A COMPROMISE BETWEEN "USE" AND "POSSESSION"}

The crime of insider trading has never been expressly defined by statute or rule. ${ }^{27}$ Instead, Congress and the SEC have been content to allow insider trading law to develop through the courts and by administrative action. ${ }^{28}$ The principal statutory authority for modern insider trading law is found in the language of Section 10(b) of the Exchange Act, ${ }^{29}$ which was implemented by the SEC in Exchange Act Rule $10 \mathrm{~b}-5 .^{30}$ Section 10(b) proscribes the employment of "any manipulative or deceptive device or contrivance" in "connection with the purchase or sale, of any security."31 .

${ }^{27}$ Section 16(b) of the Exchange Act (which prohibits short-swing trading by corporate directors, officers, and shareholders who own more than $10 \%$ of the company's stock) and SEC Rule 14e-3 (which prohibits insider trading in connection with tender offers) are perhaps exceptions, but they are strictly limited in scope and do not address the typical case of insider trading. See, e.g., STEPHEn M. Bainbridge, SECURITIES LAw: INSIDER TRAding 27 ( 2 d ed. 2007).

${ }^{28}$ See id. at 28-29. During Congressional hearings concerning the Insider Trading Sanctions Act of 1984, it was urged that the crime of insider trading be defined with specificity, but Congress opted not to do so. Carole B. Silver, Penalizing Insider Trading: A Critical Assessment of the Insider Trading Sanctions Act of 1984, 1985 DUKE L.J. 960, 988, 993.

${ }^{29} 15$ U.S.C. $\$ 78 \mathrm{j}(\mathrm{b})$. While Section $10(\mathrm{~b})$ and SEC Rule $10 \mathrm{~b}-5$ provide the principal legislative and statutory authority for the regulation of insider trading (and will be the main focus of this Article), it should be noted that insider trading cases may be based on other authority as well. The Sarbanes Oxley Act of 2002 comprises a general antisecurities fraud provision at 18 U.S.C. $\S 1348$, whereby persons may be imprisoned up to twenty-five years for "knowingly" executing a "scheme or artifice" to "defraud any person" in connection with a security of a public company or for obtaining "money or property" under "false or fraudulent pretenses" in connection with the purchase or sale of any such security. Insider traders are also sometimes prosecuted under Exchange Act Section 17(a), S.E.C. Rule 14e3 (under Exchange Act Section 14(e)). In addition, prosecutors sometimes rely on the general mail and wire fraud provisions under 18 U.S.C. $\$ \S 1341$ and 1343 in insider trading cases. E.g., Carpenter v. United States, 484 U.S. 19, 20 (1987) (defendants convicted under federal mail and wire fraud statutes in addition to Section 10(b)). Finally, even if an individual is not found guilty of fraud or deceit in connection with a securities trade, she may still be subject to criminal prosecution for a process offense such as for knowingly and willfully making a materially false representation to the SEC or a federal agent during the course of an insider trading investigation. 18 U.S.C. $\$ 1001$ (2012). This is the statutory provision under which Martha Stewart was ultimately convicted. See Joel M. Athey et al., United States: DOJ Shifts Stance on False Statements Prosecutions, MONDAQ (June 2, 2014), http://www.mondaq.com /unitedstates $/ \mathrm{x} / 3$ 17704/White+Collar+Crime+Fraud/DOJ+Shifts + Stance+on+False+Statem ents+Prosecutions, archived at http://perma.cc/2AKB-QW6E.

${ }^{30} 17$ C.F.R. $\$ 240.10 b 5-1$ (2014).

${ }^{31} 15$ U.S.C. $\$ 78 j(b)$. 
Although Congress designed Section 10(b) as a "catchall" 32 clause to give the SEC flexibility to regulate manipulation and deception in connection with securities transactions, the Supreme Court has made it clear that "what it catches must be fraud. ${ }^{\prime 33}$ The elements of insider trading liability under Section $10(\mathrm{~b})$ and Rule 10b5 must therefore resemble those of common law fraud. ${ }^{34}$ But while fraud typically requires an affirmative misrepresentation, ${ }^{35}$ insider trading usually involves silence or a failure to disclose ${ }^{36}$ Recognizing that the common law only deems silence to be fraudulently deceptive where circumstances impose a duty of disclosure, ${ }^{37}$ the Supreme Court has offered two theories under which a Section 10(b) duty to disclose exists: the "classical theory" and the "misappropriation theory.",38

Under the classical theory, the duty to disclose arises from the relationship of trust and confidence between the actual parties to the trade. ${ }^{39} \mathrm{~A}$ corporate insider who seeks to benefit from material nonpublic information by trading in her own company's shares thereby violates a "fiduciary or other similar relation of trust and confidence" ${ }^{" 40}$ to the current or prospective shareholders of the company on the other side of the transaction. Recognizing such a duty to disclose guarantees that those "who have an obligation to place the shareholder's welfare before their own, will not benefit personally [at the expense of the shareholder] through [the] use of material, nonpublic information." 41

The misappropriation theory applies to corporate outsiders who gain material nonpublic information by deception and then seek to benefit by trading on that information. ${ }^{42}$ Under the misappropriation theory, the duty to disclose arises from a duty of trust and confidence to the source of the information, not to the counterparty to the transaction. ${ }^{43}$ The misappropriator deceives "those who entrusted him with access to confidential information" by depriving them "of the exclusive use of that information. ${ }^{" 44}$ Combined, the classical and misappropriation theories complement

${ }^{32}$ Chiarella v. United States, 445 U.S. 222, 226 (1980).

${ }^{33}$ Id. at 235.

${ }^{34}$ See id. at $225-26$.

${ }^{35}$ RESTATEMENT (SECOND) OF TORTS $§ 525$ (1977).

${ }^{36}$ In the rare cases where insider trading deception does involve an affirmative misrepresentation, the duty-to-disclose requirement need not be met. E.g., SEC v. Dorozhko, 574 F.3d 42, 51 (2d Cir. 2009) (holding a hacker's gaining access to a computer database by misrepresenting his identity was an affirmative deception so no independent duty to disclose was necessary to establish the requisite deception under $10(\mathrm{~b})$ ).

${ }^{37}$ Chiarella, 445 U.S. at 228 (quoting RESTATEMENT (SECOND) OF TORTS. § 551(2)(a) (1976)).

${ }^{38}$ United States v. O'Hagan, 521 U.S. 642, 652-53 (1997).

${ }^{39}$ See Chiarella, 445 U.S. at 230; see also O'Hagan, 521 U.S. at 652 (quoting Chiarella, 445 U.S. at 228-29).

${ }^{40}$ Chiarella, 445 U.S. at 228 (quoting RestATEMENT (SECOND) OF TORTS $§ 551(2)(a)$ ).

${ }^{41} \mathrm{Id}$. at 230.

${ }^{42}$ O'Hagan, 521 U.S. at $652-53$.

${ }^{43} \mathrm{Id}$. at 653 .

${ }^{44} \mathrm{Id}$. at 652. 
one another to fill out the prohibition of insider trading as a form of Section $10(\mathrm{~b})$ fraud..$^{45}$

In addition to establishing the duty to disclose, common law fraud requires a finding of scienter. ${ }^{46}$ Accordingly, the Supreme Court has consistently asserted that liability under Section $10(\mathrm{~b})$ and Rule $10 \mathrm{~b}-5$ requires a finding of this mental state of intent to deceive or manipulate. ${ }^{47}$ For example, in Ernst \& Ernst $v$. Hochfelder ${ }^{48}$ the Supreme Court looked to the language and legislative history of Section 10(b) to reach the conclusion that mere negligence could not support liability under Rule $10 \mathrm{~b}-5 .{ }^{49}$ The Court explained that the "words 'manipulative or deceptive' used in conjunction with 'device or contrivance' strongly suggest that $\S 10(b)$ was intended to proscribe knowing or intentional misconduct" that $\S 10(\mathrm{~b})$ was intended to proscribe conduct not involving scienter."

\section{A. Use Versus Possession}

Purchases and sales of a company's shares by its insiders are quite common. Indeed, many corporate insiders receive a large portion of their compensation in firm stock. This compensation would be worthless if the shares could not be sold at some point. ${ }^{52}$ Within this context, it is easy to see how the element of scienter can complicate the already difficult task of insider trading enforcement for the SEC. Section 10(b) only prohibits insiders from trading in their own company's shares if they do so based on material nonpublic information. But there are any number of alternative, innocent explanations an insider might offer for the sale of shares: diversifying her portfolio, paying for a child's upcoming wedding or college tuition, building a new house, buying a boat, etc. Such alternative motives are easy to manufacture and difficult to disprove.

Historically, the SEC sought to overcome this challenge by taking the position that the element of scienter in Rule 10b-5 could be satisfied by the insider's knowing possession of material nonpublic information, regardless of whether it is proved the information actually caused the relevant transaction..$^{53}$ This strategy met with mixed

${ }^{45} \mathrm{Id}$. at $652-53$.

${ }^{46}$ See ReSTATEMEnT (SECOND) OF TORTS $\$ 525$ (1977).

${ }^{47}$ See Carol B. Swanson, Insider Trading Madness: Rule 10b5-1 and the Death of Scienter, 52 U. KAN. L. REV. 147, 155 (2003) (noting the Supreme Court "has repeatedly asserted that [Rule 10b-5] liability involves deceptive acts, not just bad management, and deception necessarily implicates state of mind").

48425 U.S. 185 (1976).

${ }^{49} \mathrm{Id}$. at 214 (involving alleged negligence in an audit that failed to uncover a bank president's fraudulent investment scheme).

${ }^{50} \mathrm{Id}$. at 197.

${ }^{51}$ Id. at 202; see also Santa Fe Indus., Inc. v. Green, 430 U.S. 462, 464-68 (1977) (holding Section 10(b) liability must involve intent to manipulate or deceive).

${ }^{52}$ See, e.g., Karl T. Muth, With Avarice Aforethought: Insider Trading and 10b5-I Plans, 10 U.C. DAvis BuS. L.J. 65,67 (2009).

${ }^{53}$ See BAINBRIDGE, supra note 27 , at 90. 
results in the courts. In United States $v$. Teicher, ${ }^{54}$ an attorney fed material nonpublic information about his firm's corporate client's merger and acquisition plans to others who then traded on that information. ${ }^{55}$ The tippee traders were convicted of insider trading pursuant to Section 10(b) and Rule 10b-5. ${ }^{56}$ The traders appealed their convictions by challenging, inter alia, the jury instruction that embraced the SEC's possession standard. ${ }^{57}$ In dicta, the Second Circuit endorsed the SEC's possession standard ${ }^{58}$ noting that (1) the "in connection with" language of both Section 10(b) and Rule $10 \mathrm{~b}-5$ is to be interpreted "flexibly;", (2) the mere possession standard comports with the "disclose or abstain" maxim that is so often quoted in insider trading jurisprudence; ${ }^{60}$ and (3) the "knowing possession" standard has the practical benefit of simplifying the task of enforcement. ${ }^{61}$

In SEC v. Adler, ${ }^{62}$ however, the Eleventh Circuit rejected the SEC's knowing possession standard. This case involved a corporate director's sale of shares in his own firm's stock while in knowing possession of material nonpublic information. ${ }^{63}$ The director offered the defense that the sale in question was part of a trading plan that predated his acquisition of the material nonpublic information in question. ${ }^{64}$ The court began its analysis by noting that while Section 10(b) and Rule 10b5-1 do not expressly address the question of whether an insider's mere possession of material nonpublic information at the time of trading is enough to establish liability, their language "suggests a focus on fraud, deception, and manipulation." ${ }^{65}$ Next the court recognized that the Supreme Court has repeatedly indicated, if only in dicta, that the element of scienter for insider trading under Section 10(b) and Rule 10b5-1 requires proof the insider or misappropriator "use[d]," "[took] advantage of," "on the basis of," ${ }^{68}$ material nonpublic information. In addition, the court pointed out that even the SEC has been inconsistent on the issue of "use versus possession." 69

54987 F.2d 112 (2d Cir. 1993).

${ }^{55} \mathrm{Id}$. at 114-17.

${ }^{56} \mathrm{Id}$. at 118 .

${ }^{57} \mathrm{Id}$. at 119.

${ }^{58}$ Based on the entirety of the record, the court concluded that any defect in the instruction was harmless because, even on a causal connection standard, no reasonable jury could have reached a different result. See id. at 121.

${ }^{59} \mathrm{Id}$. at 120.

${ }^{60} \mathrm{Id}$.

${ }^{61} I d$.

${ }^{62} 137$ F.3d 1325 (11th Cir. 1998).

${ }^{63} \mathrm{Id}$. at 1339.

${ }^{64} \mathrm{Id}$.

${ }^{65} \mathrm{Id}$. at 1333.

${ }^{66} \mathrm{Id}$. at 1333-34 (quoting Dirks v. SEC, 463 U.S. 646, 659-60 (1983)).

${ }^{67} \mathrm{Id}$. at 1333 (quoting Chiarella v. United States, 445 U.S. 222, 226-28 (1980)).

${ }^{68} \mathrm{Id}$. at 1334 (quoting United States v. O'Hagan, 521 U.S. 642, 651 (1997)).

${ }^{69} \mathrm{Id}$. at $1335 \mathrm{n} .26$. The Court notes that in In re Investors Mgmt. Co., [1970-71 Transfer Binder] Fed. Sec. L. Rep. (CCH), I 78,163, at 80,514, 80,519 (July 29, 1971), "the SEC concluded that one of the elements of an insider trading violation under $\S 10(\mathrm{~b})$ and Rule $10 \mathrm{~b}-5$ is that the material nonpublic information 'be a factor in the insider's decision to effect 
Ultimately, the Adler court concluded the "use test" is the most appropriate because it "best comports with the language of $\S 10(\mathrm{~b})$ and Rule 10b-5, and with Supreme Court precedent." ${ }^{\text {"70 }}$

Nevertheless, in a nod to the difficulty the SEC faces in proving use in this context, where "the motivations for the trader's decision to trade are difficult to prove and peculiarly within the trader's knowledge," "71 the court holds that "when an insider trades while in possession of material nonpublic information, a strong inference [of use] arises ...." 72 The insider can, however, "rebut the inference by adducing evidence that there was no causal connection between the information and the trade." ${ }^{" 3}$ Later that same year, the Ninth Circuit joined the Eleventh Circuit in expressly rejecting the SEC's possession test in United States $v$. Smith ${ }^{74}$ this time in the context of a criminal insider trading case. The Smith court relied heavily on the reasoning of Adler $^{75}$

\section{B. SEC Adopts Rule 10b5-1}

With two circuits rejecting the SEC's knowing possession test in the same year, the trend in the courts appeared to be in favor of requiring a causal connection between the possession of material nonpublic information and trading to establish liability under Section 10(b) and Rule 10b-5. Rather than risk further erosion of its enforcement power by the courts, the SEC proposed Rule 10b5-1 a year later in December $1999,{ }^{76}$ and it was adopted in October 2000. ${ }^{77}$

The preliminary note to Rule 10b5-1 explains that the rule "defines when a purchase or sale constitutes trading 'on the basis of' material nonpublic information in insider trading cases brought" ${ }^{\prime 78}$ under Section 10(b) and Rule 10b-5. The note adds that the law of insider trading is "otherwise defined by judicial opinions construing Rule 10b-5, and Rule 10b5-1 does not modify the scope of insider trading law in any other respect." ${ }^{, 79}$

the transaction." Adler, 137 F.3d at 1336. The court then points out that, later, in Report of the Investigation in the Matter of Sterling Drug, Inc., [1978 Transfer Binder] Fed. Sec. L. Rep. (CCH), ๆ 81,570, at 80,295, 80, 298 (Apr. 18, 1978), the SEC reversed course, stating "Rule 10b-5 does not require a showing that an insider sold his securities for the purpose of taking advantage of material non-public information." Id.

${ }^{70}$ Adler, 137 F.3d at 1337-38.

${ }^{71}$ Id. at 1337.

${ }^{72} \mathrm{Id}$.

${ }^{73} \mathrm{Id}$.

${ }^{74} 155$ F.3d 1051, 1070 (9th Cir. 1998).

${ }^{75}$ See id. at 1066-69.

${ }^{76}$ See Selective Disclosure and Insider Trading, Exchange Act Release No. 33-7787, Fed. Sec. L. Rep. (CCH) \ 86,228, at 82,846 (Dec. 20, 1999).

${ }^{77}$ See August 2000 Exchange Act Release, supra note 10, at 51,716.

${ }^{78}$ Trading "on the basis of" Material Nonpublic Information in Insider Trading Cases, 17 C.F.R. $\S 240.10 b 5-1$ (2014).

${ }^{79} \mathrm{Id}$. 
Section (a) of Rule 10b5-1 incorporates both the classical and misappropriation insider trading theories by expressly providing that among the "manipulative and deceptive devices" prohibited by Section $10(\mathrm{~b})$ and Rule 10b-5 is included the purchase or sale of a security "on the basis of" ${ }^{\text {" }}$ material nonpublic information "in breach of a duty of trust or confidence that is owed directly, indirectly, or derivatively, to the issuer of that security," its shareholders, "or to any other person who is the source of the material nonpublic information." "The "use versus possession" issue is then addressed in Section (b) by defining "on the basis of" for purposes of the rule as nothing more than being "aware" of material nonpublic information at the time of the trade. ${ }^{82}$ In defining "on the basis of" in terms of "awareness," one commentator notes "the SEC may have indulged in some linguistic legerdemain, ... arguably transforming a phrase that connotes a deliberate act ... into something less. $\$ 83$

Though the SEC chose the term "aware" rather than "possess," it appears to be a distinction without much of a difference. ${ }^{84}$ The final release announcing the rule's adoption explains that "the goals of insider trading prohibitions . . . are best accomplished by a standard closer to the 'knowing possession' standard," nevertheless, the SEC recognizes that "an absolute standard based on knowing possession, or awareness, could be overbroad in some respects." explains that the "new rule attempts to balance these considerations by means of a general rule based on 'awareness' of the material nonpublic information, with several carefully enumerated affirmative defenses." ${ }^{\text {} 77}$ The sole perceivable distinction between knowing possession and the awareness standard adopted appears to be the availability of affirmative defenses in Section (c) of the rule.

${ }^{80}$ Id. $\S 240.10 \mathrm{~b} 5-1(\mathrm{a})$; see also Swanson, supra note 47, at 191.

${ }^{81}$ Id. $\S 240.10 \mathrm{~b} 5-1(\mathrm{a})$.

${ }^{82} \mathrm{Id}$. $\$ 240.10 \mathrm{~b} 5-1(\mathrm{~b})$.

${ }^{83}$ Allan Horwich, The Origin, Application, Validity, and Potential Misuse of Rule 10b5-1, 62 Bus. LAw. 913, 921 (2007).

${ }^{84}$ The SEC has not defined the term "aware," choosing to leave it to the courts to determine whether it requires some degree of knowledge beyond mere knowing possession. See id. at 921-22.

${ }^{85}$ August 2000 Exchange Act Release, supra note 10, at 51,727. As one commentator notes, "[t]aken in isolation, this rationale simply says that lowering the threshold of liability will reach more conduct." Horwich, supra note 83, at 921.

${ }^{86}$ August 2000 Exchange Act Release, supra note 10, at 51,727.

${ }^{87} I d$. (emphasis added). 


\section{Requirements for Trading Plans as an Affirmative Defense}

Section (c) details three affirmative defenses to insider trading liability. The rule provides that a trade is not "on the basis of" material nonpublic information if the trade strictly complies ${ }^{88}$ with a binding contract, ${ }^{89}$ instruction, ${ }^{90}$ or Trading Plan ${ }^{91}$. that was entered into before "becoming aware" of the information. Since Trading Plans are central to this Article, this summary will focus exclusively on them. A Trading Plan must be written to qualify for the affirmative defense. ${ }^{92}$ It must specify the amount, price, and date of the securities to be purchased or sold ${ }^{93}$ or include a written "formula or algorithm, or computer program" that determines the same. ${ }^{94}$ In addition, the Trading Plan must not permit any subsequent influence by the person availing herself of the Plan "over how, when, or whether to effect [Plan] purchases or sales ...." If the Plan grants discretion to another person to make trades under it, that person must not be aware of material nonpublic information when doing so. ${ }^{96}$ Moreover, the affirmative defense is not available under a Plan if the person who entered into the Plan subsequently altered or deviated from its terms. ${ }^{97}$ Nor is it available if the person who entered into the Plan subsequently enters into or alters a "corresponding or hedging transaction or position with respect to those securities." A person is free to modify an existing Plan while unaware of material nonpublic information, but this has the effect of terminating the existing Trading Plan and entering into a new one. ${ }^{99}$ Finally, a Trading Plan only provides an affirmative defense to insider trading liability when it was "entered into in good faith and not as part of a plan or scheme to evade the prohibitions" of Rule $10 \mathrm{~b}-5 .{ }^{100}$

${ }^{88} 17$ C.F.R. $\S 240.10 \mathrm{~b} 5-1$ (c)(1)(i) (2014).

${ }^{89} \mathrm{Id}$ § $240.10 \mathrm{~b} 5-1(\mathrm{c})(1)(\mathrm{i})(\mathrm{A})(1)$.

${ }^{90} \mathrm{Id} . \S 240.10 \mathrm{~b} 5-1(\mathrm{c})(1)(\mathrm{i})(\mathrm{A})(2)$.

${ }^{91}$ Id. $\$ 240.10 \mathrm{~b} 5-1(\mathrm{c})(1)(\mathrm{i})(\mathrm{A})(3)$.

${ }^{92}$ Id. $\S 240.10 \mathrm{~b} 5-1(\mathrm{c})(\mathrm{1})(\mathrm{i})(\mathrm{A})$. Trading Plans differ from the other two Rule 10b5-1 affirmative defenses in this way. Neither the 10b5-1(c)(1)(i)(A)(1) contracts nor 10b51(c)(1)(i)(A)(2) instructions need be in writing to comply with the rule. See Exchange Act Rules, Questions and Answers of General Applicability, U.S. SEC. \& EXCH. Comm'N, $\mathrm{http} / / / \mathrm{www} . \mathrm{sec}$.gov/divisions/corpfin/guidance/exchangeactrules-interps.htm, archived at http://perma.cc/9URF-JBSK (last updated Feb. 13, 2012) [hereinafter SEC Interpretations] (see Question 120.24 and accompanying text).

${ }^{93} 17$ C.F.R. $\$ 240.10 b 5-1(\mathrm{c})(1)(\mathrm{i})(\mathrm{B})(1)$.

${ }^{94} \mathrm{Id}$. $\$ 240.10 \mathrm{~b} 5-\mathrm{l}(\mathrm{c})(\mathrm{l})(\mathrm{i})(\mathrm{B})(2)$.

${ }^{95} \mathrm{Id} . \S 240.10 \mathrm{~b} 5-1(\mathrm{c})(1)(\mathrm{i})(\mathrm{B})(3)$.

${ }^{96} \mathrm{Id}$.

${ }^{97}$ Id. $\S 240.10 \mathrm{~b} 5-1(\mathrm{c})(1)(\mathrm{i})(\mathrm{C})$; see also August 2000 Exchange Act Release, supra note 10 , at 51,728 .

${ }^{98} 17$ C.F.R. $\S 240.10 \mathrm{~b} 5-1(\mathrm{c})(1)(\mathrm{i})(\mathrm{C})$; August 2000 Exchange Act Release, supra note 10 , at 51,728 .

${ }^{99}$ August 2000 Exchange Act Release, supra note 10, at 51,728 n. 111.

${ }^{100} 17$ C.F.R. $\S 240.10$ b5-1(c)(1)(ii). 
It is important to note that the SEC has made it clear that it does not regard the act of terminating an existing Trading Plan while aware of material nonpublic information as a violation of Section 10(b) or Rule 10b-5. ${ }^{101}$ However, while one may terminate an existing Plan without risk of insider trading liability for the termination, the SEC has taken the position that such termination "could affect the availability of the Rule 10b5-1(c) defense for prior plan transactions if it calls into question whether the plan was 'entered into in good faith and not as part of a plan or scheme to evade' the insider trading rules." 102 If a person were to cancel just one trade under an existing Plan, this would constitute an alteration or deviation from the Plan and would result in its termination. ${ }^{103}$ To qualify for the affirmative defense, any subsequent transactions would have to be part of a new Plan. ${ }^{104}$ The affirmative defense would apply to trades under the new Plan, but only so long as they satisfy the requirements of the rule, including, of course, the requirement of good faith. ${ }^{105}$ If, after terminating an existing Plan, a person later created a new Trading Plan, then "all the surrounding facts and circumstances, including the period of time between the cancellation of the old plan and the creation of the new plan" would be taken into account in the determination as to whether the new Plan was established in good faith. ${ }^{106}$ For instance, though former Qwest Communications CEO, Joseph Nacchio, was charged for insider trading over a five-month period that spanned multiple Trading Plans, he was only found criminally liable for trades that occurred after his initial Plan was terminated. ${ }^{107}$ Thus, frequent Trading Plan modifications may jeopardize availability of the affirmative defense. ${ }^{108}$

\section{SEC's Compromise, Scienter, and Lingering Questions}

Although Rule 10b5-1's definition of "on the basis of" as mere "awareness" rejects the causal connection test endorsed in Adler, ${ }^{109}$ the availability of affirmative defenses under the rule reflects a compromise. As noted above, while the Adler court adopted the use test, it held that mere possession was enough to create a strong,

${ }^{101}$ See SEC Interpretations, supra note 92 (explaining at Question 120.17 that Section 10 (b) and Rule 10b-5 only apply to fraudulent conduct "in connection with the purchase or sale of any security").

${ }^{102}$ Id. (see Question 120.18 and accompanying text).

${ }^{103} I d$. (see Question 120.19 and accompanying text).

${ }^{104} \mathrm{Id}$.

${ }^{105} \mathrm{Id}$.

${ }^{106} \mathrm{Id}$.

${ }^{107}$ See United States v. Nacchio, 519 F.3d 1140, 1147-48 (10th Cir. 2008), vacated in part on other grounds en banc, 555 F.3d 1234 (10th Cir. 2009).

${ }^{108}$ Peter J. Romero \& Alan L. Dye, Insider Trading Under Rules 10b5-1 and 10b5-2, in Postgraduate Course in Federal Securities Law 893, 905-06 (ALI-ABA Course of Study, July 18-20, 2002) ("It would be unwise . . . for a person to engage in frequent modifications of trading plans.").

${ }^{109}$ See, e.g., BAINBRIDGE, supra note 27 , at 92-93 (stating that "Rule 10b5-1 formally rejects the Adler position"). 
though rebuttable, presumption that the requisite causal connection was present. Thus, when considering Rule 10b5-1's awareness test alongside the availability of its affirmative defenses, some commentators have suggested that the rule and Adler are not so far apart, at least not in terms of practical consequence. ${ }^{110}$

Given the trend toward the use test in the federal courts, it is likely the SEC chose to adopt this compromise rather than a strict knowing possession test to improve the new rule's chances of survival under judicial scrutiny. Nevertheless, while Rule 10b5-1 reflects a compromise between the strict knowing possession test originally advocated by the SEC and the use test in Adler, there remain clear differences. Most importantly, while any evidence sufficient to undermine the causal connection between the information and the trading may undermine presumption of use under Adler, proof of awareness under 10b5-1 can only be defeated by the strictly defined affirmative defenses detailed in 10b5-1(c). In other words, the affirmative defenses identified by the rule are exclusive. ${ }^{111}$ The SEC rejected comments suggesting that the 10b5-1 affirmative defenses should be understood as part of a nonexclusive safe harbor. ${ }^{112}$ The SEC explained that "adding a catch-all defense or redesignating the affirmative defenses as non-exclusive safe harbors would effectively negate the clarity and certainty that the rule attempts to provide." 113

Thus, an insider who trades while aware of material nonpublic information but who presents incontrovertible evidence that that information was not a cause of the trading will nevertheless be liable under the Rule 10b5-1 test for insider trading if the proof does not fit squarely within the rule's enumerated affirmative defenses. ${ }^{114}$ In other words, it appears the rule leaves the door open for one to be found liable for insider trading without intent to deceive. ${ }^{115}$ Such a result seems to fly in the face of the courts' interpretation of Section 10(b) as requiring proof of scienter, and the SEC cannot adopt rules that reach beyond the scope of their authorizing statutes. ${ }^{116}$

${ }^{110}$ See, e.g., id. at 93 ("In practice, however, the difference between Adler and Rule 10b5n1 may prove insignificant."); Stanley Veliotis, Rule 10b5-1 Trading Plans and Insiders' Incentive to Misrepresent, 47 AM. BuS. L.J. 313, 324 (2010) ("In a sense, Rule $10 \mathrm{~b} 5-1$ is an attempt to address and codify aspects of ... [Adler].").

111 See August 2000 Exchange Act Release, supra note 10, at 51,727.

${ }_{112} I d$.

${ }^{113} I d$.

${ }^{114}$ Horwich, supra note 83, at 924, 948-49; cf. SEC Interpretations, supra note 92 (explaining under Question 120.08 a situation where a trader, without knowledge, would still be liable even though default on a secured loan was the primary reason for the sale).

${ }^{115}$ See Swanson, supra note 47, at 151-52.

${ }^{116}$ See Chevron, U.S.A. Inc. v. Natural Res. Def. Council, Inc., 467 U.S. 837, 842-44 (1984) ("If the intent of Congress is clear, ... the agency[] must give effect to the unambiguously expressed intent of Congress."); BAINBRIDGE, supra note 27, at 93 ("The SEC cannot adopt rules that go beyond the scope of the statutes authorizing them."); see also Horwich, supra note 83, at 945-49 (discussing the power of the SEC, including an analysis under Chevron). 
Though the SEC remains adamant that its adoption of 10b5-1 has done nothing to diminish the element of scienter required for liability under Section 10(b) and Rule $10 \mathrm{~b}-5,{ }^{117}$ it is difficult to reconcile this position with the exclusive nature of the available affirmative defenses. ${ }^{118}$ This has led a number of commentators to question the SEC's authority to adopt Rule 10b5-1. ${ }^{119}$ Ultimately, however, even if the SEC did not exceed its authority when it decided the "use versus possession" question by adopting $10 \mathrm{~b} 5-1$, the resulting compromise walks a fine line that leaves little room for the SEC to place further limitations on the affirmative defenses available under the rule. Maintaining this delicate compromise will be crucial to any proposed reforms to the rule.

\section{INTENDED AND UNINTENDED CONSEQUENCES OF TRADING PlanS}

Since the adoption of Rule 10b5-1 in 2000, the use of Trading Plans by corporate insiders has become "ubiquitous"120 and accounts for billions of dollars of trading each year. ${ }^{121}$ The pervasive use of Trading Plans should not be surprising. There are a number of practical advantages to these Plans that make them attractive to insiders, and most of them are innocent. But regulators, scholars, and market participants have been aware of potential abuses of Rule 10b5-1 since it was first proposed. Indeed, a former commissioner of the SEC, Joseph Grundfest, admitted that weaknesses inherent to Trading Plans were "well known" by the commission and its staff at the time Rule 10b5-1 was adopted. ${ }^{122}$ Many have complained that Trading Plans are full of loopholes ${ }^{123}$ that offer a de facto "safe harbor" for "unethical behavior." 24

${ }^{117}$ August 2000 Exchange Act Release, supra note 10, at 51,727 ("Scienter remains a necessary element for liability under Section 10(b) of the Exchange Act and Rule 10b-5 thereunder, and Rule 10b5-1 does not change this.").

118 See, e.g., Horwich, supra note 83, at 922 (noting that many commentators have discredited the SEC's claims); Swanson, supra note 47, at 196-99 (discussing the duplicitous nature of Rule 10b5-1 and noting."the affirmative defenses themselves provide internal inconsistencies'); Kevin E. Warner, Note, Rethinking Trades 'On the Basis Of' Inside Information: Some Interpretations of SEC Rule 10b5-1, 83 B.U. L. REV. 281, 306 (2003) (arguing that the SEC's assurance "seems to conflict with an infallible legal logic").

119 See, e.g., BAINBRIDGE, supra note 27, at 93 ("The bulk of the evidence . . r raises serious doubts as to the validity of Rule 10b5-1."); Horwich, supra note 83, at 944.

${ }^{120}$ Pulliam \& Barry, Executives' Good Luck, supra note 6. The increase in Trading Plan use has occurred among nonexecutive directors as well as among other corporate insiders. See Pulliam \& Barry, Directors Take Shelter in Trading Plans, supra note 6, at A1 (noting that nonexecutive director use of Trading Plans has increased 55\% since 2008, compared with a $36 \%$ increase over the same period by all other corporate insiders).

${ }^{121}$ See Pulliam \& Barry, Executives' Good Luck, supra note 6.

${ }^{122}$ Siconolfi \& Eaglesham, supra note 6.

${ }^{123}$ See, e.g., Veliotis, supra note 110, at 328-30; Cooke \& Ng, supra note 6; Eaglesham \& Barry, supra note 6.

${ }^{124}$ Eaglesham \& Barry, supra note 6. 
The goal of this Part of the Article is to situate the current controversy over Trading Plans by clarifying the stakes and stakeholders. This is done, first, by identifying the benefits that the SEC intended Trading Plans would offer insiders and the market in general. Second, the unintended abuses of Trading Plans are considered. The different ways in which Trading Plans might be exploited to beat the market are identified, and studies indicating that corporate insiders are in fact using Trading Plans to beat the market are summarized. Finally, since Trading Plans must be approved by firms, this Part concludes by exploring the extent to which firms are aware of (and perhaps even complicit in) insiders' use of Plan trading to beat the market.

\section{A. Intended Uses and Benefits of Trading Plans}

Trading Plans allow insiders who are compensated in terms of stock and stock options some flexibility to liquidate and diversify without risk of criminal liability. In recent years equity compensation has become the predominate component of corporate executive pay. ${ }^{125}$ Since such compensation would be significantly diminished in value were significant restrictions placed on insiders' ability to trade, ${ }^{126}$ there should be little wonder that insiders are anxious to avail themselves of these Plans and thereby increase their flexibility to sell the shares with which they have been paid. ${ }^{127}$ And, of course, where the shares are more valuable to employees, firms can achieve the same compensation while offering fewer of them; Trading Plans, therefore, reduce costs to firms. ${ }^{128}$ The SEC expected and encouraged such efficient use of Trading Plans. ${ }^{129}$

${ }^{125}$ M. Todd Henderson, Insider Trading and CEO Pay, 64 VAND. L. REV. 505, 508 (2011) (Noting that between 1999 and 2008, "the average public company executive earned more than half her total pay in the form of stock options or restricted stock").

${ }^{126}$ See id. at 509 (noting that if insiders are restricted in their ability to sell shares to diversify their holdings, "this [restriction] will reduce the value of the shares granted"); see also Muth, supra note 52, at 67 ("To enjoy the proceeds of selling stock issued as compensation, the executive must be able to liquidate stock while in possession of inside information.").

${ }^{127}$ See Sougata Mukherjee, The Dangerous Game Corporate Executives Are Playing, TRIANGLE BIZBLOG (Dec. 11, 2012, 2:29 PM), http:/www.bizjournals.com/triangle/blog/ 2012/12/the-dangerous-game-corporate.html?page=all, archived at http://perma.cc/8ZGHKNW.

${ }^{128}$ See Henderson, supra note 125 , at 509-10.

${ }^{129}$ Linda Chatman Thomsen, then-director of the SEC Division of Enforcement, explained that part of the point of Rule 10b5-1 was "to give executives opportunities to diversify or become more liquid through the use of plans with prearranged trades without facing the prospect of an insider trading investigation." Linda Chatman Thomsen, Dir., Div. of Enforcement, U.S. Sec. \& Exch. Comm'n, Speech by SEC Staff: Opening Remarks Before the 15th Annual NASPP Conference (Oct. 10, 2007), available at http://www.sec.gov/news/ speech/2007/spch101007lct.htm, archived at http://perma.cc/WQE6-J52G; see also Henderson, supra note 125, at 516-17 (noting that 10b5-1 plans were "expected to increase opportunities for optimization trading" and "increase the value of insiders' shares"). 
Moreover, Trading Plans offer some legal certainty for insiders and firms where there was very little before. Prior to the adoption of $10 \mathrm{~b} 5-1$, general counsel across the country faced a predicament every time an officer or director requested to purchase or sell company stock. ${ }^{130}$ As one commentator put it, under the old regime, "the insider trading laws provided no means of assuring that a transaction in the company's securities by an insider would escape liability under these laws." ${ }^{\prime 131}$ Under Rule 10b5-1, however, the law offers a sanctioned approach that can be implemented by firms to moot the question of whether an insider had material nonpublic information at the time the transaction takes place. ${ }^{132}$

Finally, Trading Plans allow firms to avoid much of the adverse perception often associated with insider trades. Prior to Rule 10b5-1, there was always the concern that the market would react to insider transactions as an indication of the health of the company when, instead, the decision to trade was based on reasons unique to the trader (such as portfolio diversification). ${ }^{133}$ By disclosing that insider trading was pursuant to a Trading Plan (established without material nonpublic information and well in advance of the actual trade), firms now have a means of quelling adverse market reactions and suspicion of illegal trading. ${ }^{134}$ In addition, Trading Plans allow insiders to spread their transactions out into smaller increments over a long period of time. Such trades are less likely to attract unwarranted attention by the market than would large, dramatic chunks during the narrow trading windows following the firm's quarterly filings (typically the only means of safely liquidating shares prior to the advent of 10b5-1 Trading Plans). ${ }^{135}$

The practical advantages of Trading Plans listed above are all consistent with the SEC's stated rationale for Rule 10b5-1. But there are grounds for believing that another reason, not endorsed by the SEC, offers the principal explanation of Trading Plans' popularity, namely that they provide a de facto safe harbor for insiders to beat the market based on material nonpublic information.

130 See Donald H. Meiers, Rule 10b5-1 Trading Plans: A Win-Win Situation, METROPOLITAN CORP. COUNS., May 1, 2001, available at 2001 WLNR 12908239.

${ }^{131} I d$.

${ }^{132}$ See id.; Henderson, supra note 125, at 514; Michael S. Melbinger, SEC Announces Scrutiny of 10b5-1 Trading Plans, EXEC. COMP. BLOG (Oct. 11, 2007), http://www.winston.com/en/executive-compensation-blog/sec-announces-scrutiny-of-10b5 -1-trading-plans.html, archived at http://perma.cc/3NGB-H7CD.

${ }_{133}$ See, e.g., Romero \& Dye, supra note 108, at 901 ("Open market sales by [insiders] ... often attract unwanted attention, due to the perception of many investors that such sales may reflect a lack of confidence in the company.").

${ }^{134}$ Id. at 901-02; see also Meiers, supra note 130 ("A company's implementation of an insider trading policy ... serves to demonstrate its good faith efforts to ensure that the company and its insiders comply with the insider trading laws ....").

${ }^{135}$ See Romero \& Dye, supra note 108, at 901-02. 


\section{B. Unintended Uses of Trading Plans-Beating the Market}

As one commentator noted, until 2005 "most accepted that 10b5-1 plans were rarely abused and that scheduled trading was a good system to allow those with inside information to trade in their companies' stocks and diversify their personal holdings." ${ }^{136}$ In August 2005, however, Professor Alan Jagolinzer shared with the Wall Street Journal the preliminary results of a study finding that insiders using $10 \mathrm{~b} 5-1$ plans "earned returns on those trades that beat the market on average by $5.6 \%$ percentage points over a six-month period." 137 According to Jagolinzer's subsequently published study, Trading Plan participants' sales, which compose the majority of Plan transactions, "tend to follow price increases and precede price declines, generating statistically significant forward-looking abnormal returns." $" 138$ The study also shows that Trading Plan "initiations are associated with subsequent adverse news disclosure and that early [Trading Plan] termination is associated with positive firm performance." ${ }^{\prime 39}$ According to Jagolinzer, these results indicate that some insiders are exploiting "unintended strategic loopholes" in Trading Plans to trade strategically. ${ }^{140}$

Jagolinzer's study caught the attention of the SEC. In March 2007, Linda Chatman Thomsen, then Director of the SEC Division of Enforcement, cited to the Jagolinzer study, noting that data reflects that Trading Plans "are being abused in various ways to facilitate trading based on inside information." ${ }^{141}$ Thomsen then warned, "[w]e're looking at this-hard." "42 Despite this warning, the SEC failed to take public action. The issue faded into the background after the market collapse of 2008, only to reemerge with a series of Wall Street Journal articles in 2012 and 2013. In November 2012, the Journal ran a front-page article ${ }^{143}$ sharing the results of their own study, which found that among 20,237 executives who traded in their own company's shares within one week of their company's making news, 1,418 recorded average gains of $10 \%$ (or avoided losses of $10 \%$ within one week of their trades).$^{144}$ Only half that number saw their stock move against them by that much. The article suggests these abnormal returns can be attributed to the strategic use of Trading Plans. ${ }^{145}$

\footnotetext{
${ }^{136}$ Muth, supra note 52, at 81.

${ }^{137}$ Cooke \& $\mathrm{Ng}$, supra note 6.

${ }^{138}$ Jagolinzer, supra note 5, at 224.

${ }^{139} \mathrm{Id}$.

${ }^{140} I d$. at 225. http://perma.cc/U6GS-XZR7.

${ }^{142} I d$.

${ }^{143}$ Pulliam \& Barry, Executives' Good Luck, supra note 6.

${ }^{144} \mathrm{Id}$.

${ }^{145} \mathrm{Id}$.
}

${ }^{141}$ Linda Chatman Thomsen, Dir., Div. of Enforcement, U.S. Sec. \& Exch. Comm'n, Speech by SEC Staff: Remarks at the 2007 Corporate Counsel Institute (Mar. 8, 2007), available at http://www.sec.gov/news/speech/2007/spch030807lct $2 . \mathrm{htm} \# 19$, archived at 


\section{The Firm's Role}

A recent study by Professor M. Todd Henderson suggests that, not only are boards aware that company executives are availing themselves of Trading Plans to profit from material nonpublic information, they "bargain" with executives over such opportunities when setting executive pay. ${ }^{146}$ Henderson explains that different firms treat insider trading differently. Some firms ban all insider trading, some restrict it through blackout periods, and some grant insiders great flexibility to trade. ${ }^{147}$ Henderson points to a prior study reflecting that "firms restricting insiders' ability to trade pay about $13 \%$ more in total compensation than firms permitting insiders to trade freely." 148 The implication is that some firms offer more liberal insider trading policies as a form of "implicit compensation." 49 The value of this compensation does not stem entirely from optimization trading (or diversification), which was an intended benefit of Trading Plans. ${ }^{150}$ Henderson's study shows that a reduction in pay correlates to expected returns from informed trading as well: "For insiders at firms where prior work shows informed trading is more likely and where, in expectation, insiders are likely to earn abnormal returns from this trading, we see statistically significant differences in pay compared with insiders at firms where prior work shows informed trading is much less likely." evidence that firms and executives bargain about insider-trading profits, both from optimization trades and informed trades, and that these profits are considered in meeting an executive's reservation wage." ${ }^{152}$ Thus, Henderson concludes:

[T]he data suggest[s] that the board was relatively better informed about the expected use of Rule 10b5-1 trading plans than the SEC, who wrote the rule. If we take the SEC at its word that Rule 10b5-1 was intended to encourage optimization trades but not informed trades, then the SEC made

${ }^{146}$ Henderson, supra note 125 , at 506-07, 537.

${ }^{147} \mathrm{Id}$. at $506-07,513$.

148 Id. at 515 (citing Darren Roulston, The Relation Between Insider-Trading Restrictions and Executive Compensation, 41 J. ACCT. RES. 525, 525-26 (2003)).

149 See Henderson, supra note 125, at 507 (describing the concept of "implicit compensation" as "compensation that is not explicitly disclosed to the public but is nevertheless part of the pay bargain between board and executive").

${ }^{150}$ Diversification is key to risk management in any investment portfolio. When firms offer stock as compensation, employees will be exposed to significant risk unless they can liquidate those shares and diversify their assets. When an insider trades for the purpose of optimizing the balance and diversification of her investment portfolio, rather than to profit from material nonpublic information, this is called "optimization trading." Stock compensation is worth less to employees when optimization trading is restricted. See Henderson, supra note 125, 509-22. Part of the rationale behind the adoption of 10b5-1(c) Trading Plans was to offer employees greater flexibility to liquidate their firm stock for purposes of diversification without the risk of insider trading liability. See, e.g., Thomsen, supra note 129.

${ }^{151}$ Henderson, supra note 125 , at 537.

${ }^{152}$ Id. 
a mistake - the Rule encourages both types of trades. The evidence ... suggests that boards were aware of this potential in the Rule. ${ }^{153}$

If companies are complicit in their insiders' use of material nonpublic information to beat the market through the use of Trading Plans, as Henderson's study suggests they are, then what is to be done about it? What is the legal status of such implicit compensation?

\section{DiD 10B5-1 LEGALIZE NeW FormS OF INSIDER TRADING?}

In her 2007 speech referenced above, then Director of Enforcement Thomsen stated, "if executives are in fact trading on inside information and using a [Trading Plan] for cover, they should expect [10b5-1(c)] to provide no defense." ${ }^{54}$ But as one commentator noted, Thomsen "did not explain how such conduct violated the law or under what circumstances an affirmative defense under Rule 10b5-1 would not be available." 155

Just two weeks after the Wall Street Journal published the first article in its series on Trading Plans in late 2012, the Manhattan U.S. Attorney's office launched a broad criminal investigation into whether these Plan trades violated securities laws. ${ }^{156}$ But if, as some suggest, many insiders and firms are simply exploiting "loopholes" in Trading Plan regulations, then there may be no grounds for enforcement action. Instead, if action is to be taken, it must take the shape of legal reform.

This Part addresses the legality of using Plans to trade strategically. While the introduction of Trading Plans left much of the landscape of insider trading liability unchanged, it (1) made some clearly illegal forms of insider trading more difficult to detect and prosecute, and (2) it created new opportunities for insiders to profit legally from material nonpublic information.

\section{A. The Rule Does Not Affect the Status of Traditional Forms of Insider Trading, but It Complicates Enforcement}

As explained above, for a Trading Plan to qualify for the affirmative defense the insider must not be aware of material nonpublic information at the time it is adopted. Moreover, Rule 10b5-1 precludes any subsequent influence over the content of a qualified Trading Plan once it is established. The rule, therefore, leaves no room for traditional insider trading where the insider simply enters a buy or sell order based on material nonpublic information. Nevertheless, there is much in the rule that makes such traditional insider trading easier to engage in, and more difficult to detect and prosecute.

\footnotetext{
${ }^{153} \mathrm{Id}$. at 554.

154 Thomsen, supra note 141.

${ }^{155}$ Horwich, supra note 83, at 951 n.181.

${ }^{156}$ Pulliam et al., supra note 1 , at Al.
} 
First, most companies impose blackout periods during which their employees are not permitted to trade in firm shares. ${ }^{157}$ These blackout periods typically precede important news release dates throughout the year (e.g., prior to quarterly and annual reports). ${ }^{158}$ But because many companies permit employee trades through preexisting Trading Plans to occur during blackout periods, ${ }^{159}$ insiders in those companies gain access to strategic trading opportunities that were not available prior to the adoption of $10 \mathrm{~b} 5-1 .^{160}$

Second, illegal insider trading under the guise of Trading Plans is made easier by the fact that the rule places no limits on how soon the first trade may take place after a Plan is established. ${ }^{161}$ For example, an insider could learn of material nonpublic information, set up a Trading Plan, and begin trading under the Plan all over the course of a few days. ${ }^{162}$ Such trading unquestionably violates the rule, but the very fact that the company can respond to inquiries concerning the trade by explaining they were part of a Trading Plan offers prima facie cover and may forestall further investigation. ${ }^{163}$

Third, there is currently no requirement that firms disclose the establishment of Trading Plans by their insiders, much less that they disclose the details of any such plans. ${ }^{164}$ The lack of any disclosure requirement arguably makes illegal Plan trading

${ }^{157}$ See William K.S. WANG \& MARC L. Steinberg, InSider Trading $§ 13: 6.2$, at 13113 (Practicing L. Inst., 2d. ed. 2006).

${ }^{158} \mathrm{Id}$.

${ }^{159}$ See Henderson, supra note 125 , at 514.

160 See Jagolinzer, supra note 5, at 226.

${ }^{161}$ See, e.g., Melbinger, supra note 20 ("Rule 10b5-1 does not impose any minimum waiting period between the date that the insider adopts the plan and the date of the first trade.").

162 Indeed, Jon Hess, CEO of Hess Corporation, established a Trading Plan in February 2011 and began selling under the Plan on February 7, 2011. See Pulliam \& Barry, Executives' Good Luck, supra note 6; Pulliam \& Barry, Investors Call for More Disclosure, supra note 6. Also, on March 9, 2006, Jeffrey Lorberbaum, the chairman and CEO of Mohawk Industries Inc., established a Trading Plan. See Pulliam \& Barry, Executives' Good Luck, supra note 6 . He began selling shares under the Trading Plan just six days later on March 15. Id. Over the next two weeks, he sold over $\$ 10$ million in shares. Id. On March 30, which was the day after his last sale, the company announced lower than expected earnings and the stock dropped $5.4 \%$. Id.

163 See, e.g., In re Immucor Inc. Sec. Litig., No. 1:05-CV-2276-WSD, 2006 WL 3000133 , at *18 n.8 (N.D. Ga. Oct. 4, 2006) ("[A] clever insider might 'maximize' their gain from knowledge of an impending price drop . . . and seek to disguise their conduct with a 10b5-1 plan.").

${ }^{164}$ In 2002, the SEC proposed a rule that would have required directors and executive officers of publicly traded companies to disclose the "adoption, modification or termination" of a Trading Plan in a public filing. Form 8-K Disclosure of Certain Management Transactions, 67 Fed. Reg. 19,914 (Apr. 23, 2002) (to be codified at 17 C.F.R. pts. 230, 239, 249) [hereinafter Form 8-K Disclosure]. The proposed rule change was not, however, adopted and appears to have been tabled indefinitely. See Horwich, supra note 83, at 935 (stating that the proposal "appears to have been consigned to oblivion"). 
more profitable (because the market will not have an opportunity to adjust the stock price in anticipation of the insider's planned trading), and more difficult to detect.

Fourth, an insider may adopt multiple, inconsistent Trading Plans to create subsequent opportunities for insider trading by Plan termination. ${ }^{165}$ For example, three months prior to an earnings release, an insider might establish two Trading Plans: one Plan orders the sale of 10,000 shares on the day before the release and one orders the purchase of 10,000 shares on the day before the release. Then, two days prior to the release, when the insider possesses material nonpublic information about the substance of the release, she can terminate the buy order, or the sell order, or both, depending on the nature of the news. Rule 10b5-1(c)(1)(i)(C)'s prohibition against entering into or altering a "corresponding or hedging transaction or position" would deprive the insider of the affirmative defense, and this conduct would therefore be illegal under the rule. ${ }^{166}$ Nevertheless, again, the fact that Trading Plans need not be disclosed could make it difficult for the SEC or shareholders to detect the existence of the inconsistent Trading Plan.

Fifth, even where firms voluntarily disclose the establishment of Trading Plans, the affirmative defense shifts the "awareness" test to the date the Plan was established (rather than the execution date of Plan trades). This makes it more difficult for the SEC and shareholders to link awareness of material nonpublic information to the execution of a suspicious trade. ${ }^{167}$ Imagine an insider sells shares under a Trading Plan (which was established two months prior) on the day before a very disappointing earnings release. Under the rule, challenging the trade would require proof of awareness two months ago, which would be much more difficult than the relatively simple task of proving awareness of the substance of the earnings release on the day before it occurred. ${ }^{168}$

Ultimately, however, while the adoption of Rule 10b5-1 may have created these new opportunities for insiders to profit by trading on material nonpublic information and avoid detection, the rule did not change the legal status of any of the conduct outlined above - it was all illegal before the rule, and it all remains illegal under the rule. Trading Plans did, however, alter the legal status of other forms of strategic insider trading. This is the subject of the next section.

165 See Melbinger, supra note 20.

16617 C.F.R. $\S 240.10 b 5-1(\mathrm{c})(1)(\mathrm{i})(\mathrm{C})$ (2014); see also Brandon C. Parris, Rule 10b51 Plans: Staying Out of Trouble, 17 ABA BuS. L. TODAY, May/June 2008, available at http://apps.americanbar.org/buslaw/blt/2008-05-06/parris.shtml, archived at http://perma.cc /3GJA-JGEC (" $[1] \mathrm{t}$ would be difficult to defend this practice as not being manipulative of Rule 10b5-1.").

${ }^{167}$ See Jagolinzer, supra note 5, at 226.

${ }^{168}$ See id. at 224. 


\section{B. Loopholes Created by Trading Plans}

A legal "loophole" is a gap or ambiguity in a law that allows one to contravene the spirit or intent of a law without violating its letter. In the context of insider trading regulation, any opportunity for insiders to use material, nonpublic information to maximize profits from the purchase or sale of their own company's shares without violating the law would constitute a loophole. It is important to distinguish a loophole from a complication or challenge to efficient enforcement (the subject of the last section). Insiders exploiting a true loophole are not subject to enforcement. The only way to prevent the exploitation of a loophole is to close it with new law. The introduction of Trading Plans introduced at least two loopholes in insider trading regulation. First, they allow insiders to accelerate or delay the release of news to maximize profits for prearranged Plan trades. Second, Trading Plans have created an opportunity for insiders to enjoy risk-free options through the selective termination of qualified Plans.

\section{Altering Timing of Disclosure}

With the adoption of Rule 10b5-1, insiders found that they were no longer required to refrain from trading while in possession of material nonpublic information, provided those trades were prearranged and comprised by a qualified Plan. This created a new opportunity. Since insiders also control the timing of disclosures, the rule freed them to time the release of subsequently obtained material nonpublic information so as to maximize profits for their prearranged trades. ${ }^{169} \mathrm{~A}$ number of commentators have identified strategic acceleration or delay of an otherwise lawful release of information ${ }^{170}$ to benefit prearranged Plan transactions as a "loophole" created with the adoption of Rule 10b5-1. ${ }^{711}$ Jagolinzer's study found on average Trading Plan initiation precedes adverse news that moves the stock

${ }^{169} \mathrm{Id}$. at 226-27; see also Muth, supra note 52, at 70-71 (explaining that the plan's unusually short timeline allows executives to strategically execute a trade at a time when they would have deniability of an untoward motive).

${ }^{170}$ See, e.g., Horwich, supra note 83, at 953. It is assumed that (1) the release is true, and (2) that, in the case of delay, an earlier disclosure was not otherwise required by law or rule. See Form 8-K Disclosure, supra note 164, (noting current disclosure laws and proposing a rule requiring more timely disclosure to better inform investor decisionmaking).

171 See Veliotis, supra note 110 , at 330 (noting that insiders are free to "accelerate the release of good news ahead of planned stock sales and to delay the release of bad news until after sales are completed"); see also Horwich, supra note 83, at 952-53 (explaining no one is "deceived" by a delayed or accelerated disclosure that is in reality a violation of 10b-5); Jagolinzer, supra note 5, at 226-27 (explaining the plan's unusually short timeline allows executives to strategically execute a trade at a time when they would have deniability of an untoward motive); Muth, supra note 52, at 70-73 (discussing that "executives, rather than tampering with their plans, will simply adjust the release of news . . . to suit the plan already in place," and providing examples of executives withholding news, changing the timing of the news, or manipulating the source of the news). 
$-9.9 \%$ by 72.2 days. ${ }^{172}$ According to Jagolinzer, this indicates insiders are either establishing plans while in possession of material nonpublic information or are altering the timing of disclosures until after the trades have been planned. ${ }^{173}$

Since timing the release of material nonpublic information learned after the Plan trades were set is not a subsequent modification to the Trading Plan, such conduct does not violate Rule 10b5-1. As one commentator puts it, "[a]s long as an insider in possession of any information is 'toying with' the timing of the release of information and is not adjusting the timing of transactions under the plan, the insider is not violating the rule." 174 Moreover, it does not appear that timing the release of information to maximize profits for Plan trades is deceptive under Section 10(b) or Rule 10b-5. ${ }^{175}$ After all, who is deceived by the timing of a truthful and otherwise lawful disclosure? The point is made most saliently by considering the scenario in which true, good news is released early to maximize profits under a Plan sale (or bad news is accelerated to maximize a buy order). There is certainly no basis for the claim that accelerated disclosure of truthful information is deceptive. ${ }^{176}$

Beyond timing the release of news to maximize Trading Plan profits, one commentator has noted that insiders can also profit from timing the news itself. ${ }^{177}$ Insiders could, for example, push to accelerate or delay the signing of a firm contract to benefit Plan trades. ${ }^{178}$ Since there is rarely a "correct" or clear maximally beneficial date on which a contract should be signed, such influence on timing may be quite harmless to the firm. If it were not harmless-if, say, the influence on timing resulted in less beneficial contractual terms--then there would be a clear breach of fiduciary duty. The point is that Rule 10b5-1 opens a new space within the law for insiders to tinker with the timing of disclosures to benefit their trading.

\section{Selective Termination of Plans}

While Section 10(b) and Rule 10b-5 prohibit insiders from trading based on material nonpublic information, they do not prohibit insiders from abstaining from trading based on such information. Professor Henry Manne and others have highlighted "insider abstention"179 as an example of inconsistency in insider trading

172 Jagolinzer, supra note 5, at 235.

${ }^{173}$ Id. at 237.

174 Veliotis, supra note 110 , at 330.

175 See Horwich, supra note 83, at 952-53.

176 But even in the case of the delayed release, assuming the actual timing of the disclosure is otherwise lawful (e.g., it is not required to be disclosed on Form 8-K or on an intervening $10-\mathrm{K}$ or $10 \mathrm{Q}$ filing), it is hard to see how the delay itself can be regarded as a deception. As Professor Horwich puts it, "Accepting as a given that the actual timing of the disclosure is independently lawful, no one is 'deceived' by a delayed or accelerated corporate disclosure in violation of Rule 10b-5." Horwich, supra note 83, at 952.

${ }^{177}$ Muth, supra note 52, at 70-71.

${ }_{178}$ See id. at 71 n.33.

${ }^{179}$ I borrow this phrase from Professor Jesse M. Fried. See generally Jesse M. Fried, Insider Abstention, 113 YALE L.J. 455 (2003) (discussing insiders use of material nonpublic 
law. ${ }^{180}$ As Manne put it, "[r]efraining from selling stock that would otherwise have been sold has exactly the same economic effect on market price as a decision to buy that same number of shares."

upshot of all this is that people can make abnormal profits in the stock market simply by knowing when not to buy and when not to sell. They will not make as much perhaps as if they could trade on the information more efficiently, but nonetheless they will still make supra-competitive returns. ${ }^{182}$

Professor Jesse Fried has challenged the claim that insider abstention offers a market advantage to insiders. ${ }^{183}$ According to Fried, so long as insiders remain unable to actually trade while aware of material nonpublic information, "their ability to abstain from trading on such information does not give them an advantage over public shareholders." 184 The reason insiders who cannot trade while aware of material nonpublic information do not gain an advantage over the market by insider abstention is that any gains made by an insider who can abstain from a sale when she learns of impending good news will be offset by the fact that she will be unable to sell upon learning of impending bad news. ${ }^{185}$ In short, Fried explains, "the insider's ability to abstain on nonpublic information indicating that a planned trade would be unfavorable merely compensates the insider for her inability to proceed with a trade after learning nonpublic information indicating that the planned trade would be favorable." ${ }^{, 186}$ But Fried recognizes that the adoption of Rule 10b5-1, with its affirmative defense for trades made pursuant to prearranged Plans, has upset this equilibrium. ${ }^{187}$

The SEC has made clear the act of terminating an existing Trading Plan while aware of material nonpublic information does not violate the law because it does not involve the sale or purchase of a security. ${ }^{188}$ So, for example, if an insider's Trading Plan provides for the sale of 10,000 shares of her company's stock on the day before an earnings release, and she subsequently learns the company will beat analyst expectations, she may terminate the Plan based on this information. ${ }^{189}$ Fried points out that the ability to trade while aware of material nonpublic information under

information to abstain from trading and avoid violating Rule 10b-5).

${ }^{180}$ See e.g., Anderson, supra note 25, at 26; Henry G. Manne, Insider Trading and Property Rights in New Information, 4 CATO J. 933, 933-35 (1985).

${ }^{181}$ Manne, supra note 180, at 938.

$182 \mathrm{Id}$.

${ }^{183}$ See Fried, supra note 179, at 456-58.

${ }^{184} \mathrm{Id}$. at 458.

${ }^{185}$ See id. at $455-58$.

${ }^{186} \mathrm{Id}$. at 467.

${ }^{187} \mathrm{Id}$. at 486-87.

${ }^{188}$ See SEC Interpretations, supra note 92 (see Question 120.17 and accompanying text).

${ }^{189}$ See Jagolinzer, supra note 5, at 227; Veliotis, supra note 110, at 329. 
Rule 10b5-1, when combined with the ability to terminate a Trading Plan while aware of material nonpublic information, introduces a previously nonexistent opportunity for profit from insider abstention. ${ }^{190}$

A number of other commentators have identified the ability to selectively terminate Trading Plans based on material nonpublic information as a loophole in Rule $10 \mathrm{~b} 5-1 .{ }^{191}$ Insiders can enhance their strategic use of Trading Plan terminations by basing Plan trades on nonpublic information that is not material at the time the plan is established, but which may ripen into material information at the time the trades are scheduled to take place. ${ }^{192}$ If the information does not pan out as expected, the insider may just terminate the plan. In effect, the ability to terminate Trading Plans based on material nonpublic information allows insiders to create a cost-free option to buy or sell. ${ }^{193}$ Indeed, Jagolinzer's study found that $46 \%$ of a random sample of Trading Plan terminations of sell orders preceded positive news events for the company, while only $11 \%$ of sell order terminations preceded negative news events. ${ }^{194}$

Of course, the SEC has qualified its approval of strategic Trading Plan terminations by warning that (1) early termination may deprive the insider of the affirmative defense for prior transactions under the Plan, ${ }^{195}$ and (2) frequent early terminations may raise concerns over whether the insider established any new Trading Plans in good faith. ${ }^{196}$ These qualifications appear to significantly diminish the impact of the selective termination loophole because they seem to preclude the regular use of selective termination as an investment strategy. The insider may be able to avoid liability for the strategic termination of a single Plan trade, but at the price of potentially undermining the affirmative defense for any trades executed under the terminated or subsequent Plans. There are, however, two points to be made about this SEC guidance. First, it is phrased in vague terms that employ the

${ }^{190}$ See Fried, supra note 179 , at 456-57.

191 See Horwich, supra note 83, at 951; Jagolinzer, supra note 5, at 227; Veliotis, supra note 110, at 329; Cooke \& Ng, supra note 6 (quoting Harvard Business School Professor, Constance Bagley: "I just think [selective termination is] such a major loophole in terms of that particular rule' ... [because it allows insiders to] 'get rid of the bad trades and keep what look like the good trades."').

${ }^{192}$ Of course, though technically legal, this strategy is quite risky given the notoriously ambiguous standard of materiality as applied in the context of insider trading. See, e.g., BAINBRIDGE, supra note 27, at 34-35 (stating that the probability/magnitude balancing test for materiality adopted by the Supreme Court in Basic Incorporated v. Levinson, 485 U.S. 224 (1988), "sounds technically sophisticated and precise, [but] in fact it is inherently subjective and indeterminate"); see also Parris, supra note 166 (stating that "careful consideration should be given" to adopting a Trading Plan when in possession of nonmaterial information that could become material).

${ }^{193}$ See Veliotis, supra note 110 , at 329.

194 Jagolinzer, supra note 5, at 235.

195 See SEC Interpretations, supra note 92 (see Question 120.18 and accompanying text).

${ }^{196} I d$. (see Question 120.19 and accompanying text). 
noncommittal language, "could affect the availability"197 and "would be relevant to a determination." 198 Second, the warnings were issued as Compliance and Disclosure Interpretations, which merely reflect the "views of the staff" and are not "rules, regulations, or statements of the Commission." "99 While it would certainly be risky and unwise to ignore this guidance in practice, it is not binding on the courts and it certainly warrants close scrutiny. The next two sections test the legitimacy of this SEC guidance.

\section{Does the Constraint of Good Faith Close the Loopholes?}

Again, Rule 10b5-1(c)(1)(ii) provides that the affirmative defense of a Trading Plan is only available when the Plan was entered into "in good faith and not as part of a plan or scheme to evade the prohibitions of this [rule]. ${ }^{" 200}$ Focusing first on selective termination, how might the selective termination of a Plan trade put an insider on the wrong side of this provision? As noted above, the SEC makes it clear that the termination of a Plan based on material nonpublic information does not violate the rule because it does not involve the purchase or sale of a security. But, as noted above, the SEC also implies that such a termination may undermine the affirmative defense for prior and subsequent Plan trades. The idea must be that selective termination may be evidence that the insider understood at the time she established the plan that she would terminate the Plan if she later acquired material nonpublic information that a prearranged Plan trade would be disadvantageous. Since such a "plan or scheme" would evade the general goal of Rule 10b-5 by allowing insiders to systematically gain a market advantage through the use of material nonpublic information, the Trading Plan would never have been qualified and the affirmative defense would not therefore be available for any trades that actually took place under the Plan. Similarly, if the creation of a new Plan after a selective termination were part of the same "plan or scheme," none of the trades under that Plan would qualify for the affirmative defense either. Of course, even on this account, the affirmative defense would still stand if the thought of terminating based on material nonpublic information only occurred to the insider after the Plan was established.

If this is indeed the qualification the SEC has in mind, how would it play out in practice? Imagine the CEO of ABC, Inc. sets up a Trading Plan to sell off 100,000 shares of her $\mathrm{ABC}$ stock to diversify her portfolio. The Plan calls for the sale of 50,000 shares on the next two Fridays. When she sets up this Plan, the CEO has no material nonpublic information, but she intends to cancel the Plan if she subsequently learns $A B C$ will release negative market-moving information prior to

${ }^{197}$ Id. (see Question 120.18 and accompanying text).

${ }^{198}$ Id. (see Question 120.19 and accompanying text).

199 Div. of Corp. Fin., Compliance and Disclosure Interpretations, SEC. \& EXCH. COMM'N, http://www.sec.gov/divisions/corpfin/cfguidance.shtml, archived at http://perma. cc/Z4BK-U9HH (last modified Jan. 26, 2015).

${ }^{200} 17$ C.F.R. $\S 240.10$ b5-1(c)(C)(ii) (2014). 
any of the scheduled trades. The Thursday before the first Plan trade is to be executed, the $\mathrm{CEO}$ learns $\mathrm{ABC}$ will miss its previously published earnings guidance by $10 \%$ and that this information will be released next Thursday during a regularly scheduled earnings call. While aware of this information, the CEO allows the first trade to go through, but then cancels the Plan to prevent the second trade from being executed. The CEO's share sale on the Friday before the announcement catches the SEC's attention and there is an inquiry. In her voluntary interview with the SEC, the CEO candidly explains the trading strategy outlined above, including the fact that she established the Plan with the intention to terminate it if she learned marketmoving bad news would be announced prior to a Plan trade. Should the CEO be found liable for insider trading?

Based on the staff's interpretations, it might be expected the SEC would find the CEO entered into the Trading Plan in bad faith, as part of a "plan or scheme to evade" the prohibitions of Rule 10b-5. Consequently, the CEO's Plan would not afford her an affirmative defense. Since the CEO was "aware" of material nonpublic information at the time the first Plan trade was executed, and since no affirmative defense is available, she would be liable for insider trading with respect to this sale pursuant to Section 10(b) and Rule 10b-5 under this interpretation of Rule 10b5-1.

But this logic is troubling. First, since the SEC admits the termination of an order based on material nonpublic information is not a violation of Section 10(b) or Rule $10 \mathrm{~b}-5$, how can one's intent to selectively terminate a transaction at the time a Trading Plan is established constitute a plan or scheme to evade Section 10(b) or Rule 10b-5? Second, given the fact that it is perfectly legal to terminate a Plan based on material nonpublic information, anyone setting up a plan would be irrational not to expect to terminate the Plan if it turns out that subsequently revealed material nonpublic information will make going through with the trades financially disastrous. Third, note the odd result of depriving the CEO of the affirmative defense post hoc. The CEO made the first Plan sale solely for the purpose of diversifying her portfolio holdings. She did not use the material nonpublic information in her possession to gain an unfair advantage over the counterparty to this trade. Nevertheless, since she was "aware" of the material nonpublic information at the time the trade took place, she would be liable pursuant to Rule 10b5-1 without any evidence of scienter.

Of course the SEC's objection to the practice of selective termination might be more general. It might be that such a plan or scheme betrays bad faith in that it violates the "spirit," if not the letter of the law, and that this alone offers grounds for depriving an insider of the affirmative defense under Rule 10b5-1(c). The SEC has not issued any guidance or offered any interpretation of Rule 10b5-1 as it pertains to accelerating or delaying the release of information to benefit Plan trades, ${ }^{201}$ but a similar argument might be expected in that context. In short, the logic may be that

${ }^{201}$ In Malin v. XL Capital Ltd., 499 F. Supp. 2d 117, 156 (D. Conn. 2007), aff'd, 312 Fed. App'x 400 (2d Cir. 2009), the plaintiffs raised the issue of the timing of disclosure to fit Plan transactions, but the court dismissed the case on other grounds without addressing the timing question. See Veliotis, supra note 110, at 340-41. 
insofar as both selective termination and timing the release of information offer insiders opportunities to use Trading Plans to increase their trading profits from the use of material nonpublic information, they violate the spirit of Section 10(b) and therefore reflect bad faith.

If this is indeed the SEC's position, it defines "good faith" based on the SEC's own expansive interpretations of the goals of Section 10(b). There is, however, ample evidence of disagreement between the SEC and the federal courts over precisely what the "spirit" of the prohibition of insider trading found in Section 10(b) entails.

\section{The "Spirit" Versus "Letter" of Insider Trading Law}

The courts' rejection of the SEC's position in the "use versus possession" debate in Adler and Smith offers just one example of many in which federal courts have demonstrated a readiness to reign in the SEC's aggressive interpretations of Section 10 (b) in the context of insider trading. Most notably, the Supreme Court rejected the SEC's expansive interpretation of Section $10(\mathrm{~b})$ as a mandate for parity of information in the markets. In In re Cady, Roberts \& Co. ${ }^{202}$ the SEC maintained that one of the "principal elements" on which Section 10(b) and Rule 10b-5 insider trading liability rests is "the inherent unfairness involved where a party takes advantage of [material nonpublic information] knowing it is unavailable to those with whom he is dealing." ${ }^{203}$ The SEC's position that equal access to information was a principal rationale behind insider trading liability was picked up by the federal courts in SEC v. Texas Gulf Sulphur Co. ${ }^{204}$ and then persisted for the better part of two decades before the Supreme Court explicitly rejected it in Chiarella $v$. United States. ${ }^{205}$ In Chiarella, the Court held the SEC's formulation of the broad parity of information rule, "which departs radically from the established doctrine that duty arises from a specific relationship between two parties, ... should not be undertaken absent some explicit evidence of congressional intent.,"206 The Court then reaffirmed its rejection of the SEC's equal access rule three years later in Dirks v. SEC. ${ }^{207}$

20240 S.E.C. 907 (1961).

${ }^{203} \mathrm{Id}$. at 912.

204401 F.2d 833, 848 (2d Cir. 1968) (finding "Rule [10b-5] is based in policy on the justifiable expectation of the securities marketplace that all investors trading on impersonal exchanges have relatively equal access to material information").

205445 U.S. 222 (1980).

${ }^{206} \mathrm{Id}$. at 233.

${ }^{207} 463$ U.S. 646, 656 n.15 (1983) ("As we emphasized in Chiarella, mere possession of nonpublic information does not give rise to a duty to disclose or abstain; only a specific relationship does that."). 
Chiarella and Dirks significantly diminished the SEC's enforcement mandate. Since those decisions, the SEC has had some success ${ }^{208}$ and some failure ${ }^{209}$ in its attempts to regain the ground it lost. But regardless, it remains the case that the SEC and the courts often find themselves at odds with respect to Section 10(b)'s mandate, and therefore the scope of insider trading liability. Consequently, the SEC's understanding of "good faith" and conformity with the "spirit" of the law of insider trading is often quite different from that of the courts. Given the SEC's obvious organizational incentives to continue to press for a broader mandate, ${ }^{210}$ this gap between interpretations is likely to persist. Since it is by no means clear what is entailed by the "spirit" of Section 10(b) and therefore Rule 10b-5, there are serious moral and constitutional problems with turning to so vague a ground in defining the scope of civil and criminal liability (and available defenses) under the "good faith" provision of Rule 10b5-1(c)(1)(ii).

One of the crucial moral presuppositions of Western liberal jurisprudence is the principle of legality (sometimes expressed in the Latin phrase, Nullum crimen sine lege). ${ }^{211}$ The principle requires that "there must be no crime or punishment except in accordance with fixed, reasonably specific, and fairly ascertainable preestablished law." 12 The principle gives expression to the basic moral intuition that individuals

${ }^{208}$ For example, after Chiarella, the SEC adopted Rule 14e-3, which imposes strict liability for trading based on material nonpublic information in connection with a tender offer, to close the enforcement left open by the Court's decision in that case. 17 C.F.R. $\S$ $240.14 \mathrm{e}-3$ (2014). Rule 14e-3 was later upheld in O'Hagan. See United States v. O'Hagan, 521 U.S. 642, 666-67 (1997) (holding that "to the extent relevant to this case" the SEC "did not exceed its authority" in adopting 14e-3). However, as Professor Swanson points out, by using the language "to the extent relevant to this case," the O'Hagan Court qualified its endorsement of the rule, leaving open whether the Court "would uphold Rule $14 \mathrm{e}-3$ in a case involving a trader who otherwise owes no disclosure obligation." Swanson, supra note 47, at 180. The Supreme Court in O'Hagan also endorsed the SEC's proposed misappropriation theory of liability. 521 U.S. at $652-53,659$.

${ }^{209}$ The courts' rejection of the SEC's preferred knowing possession standard in Adler and Smith was addressed above. See also SEC v. Maxwell, 341 F. Supp. 2d 941, 948 (S.D. Ohio 2004) (rejecting an attempt by the SEC to revive tipper/tippee liability where the tipper does not personally benefit from the use of the material nonpublic information); SEC $v$. Switzer, 590 F. Supp. 756, 766 (W.D. Okla. 1984) (rejecting theory that insider trading liability could turn on information that was overheard without the insider's knowledge).

${ }^{210}$ In summarizing the "public choice" theory as an explanation for the regulation of insider trading, Professor Stephen M. Bainbridge notes, "as do all government agencies, the SEC desired to enlarge its jurisdiction and enhance its prestige. Administrators can maximize their salaries, power, and reputation by maximizing the size of their agency's budget. A vigorous enforcement program ... . is surely an effective means of attracting political support for larger budgets." BAINBRIDGE, supra note 27, at 148; see also MICHAEL P. DOOLEY, FUNDAMENTALS OF CORPORATION LAW 816-57 (1995) (describing the challenges presented by the SEC's limited resources for enforcement of insider trading laws).

${ }^{211}$ See, e.g., DAVID A.J. RICHARDS, THE MORAL CRITICISM OF LAW 195 (1977).

212 Id. 
should have fair notice that criminal sanctions will be imposed for certain conduct so they can plan their lives to avoid those sanctions.

This sound moral principle finds expression in the U.S. Constitution through the prohibition of ex post facto laws ${ }^{213}$ and through the due process clauses of the Fifth and Fourteenth Amendments. So, for example, a criminal statute that contains terms that are too vague to identify with precision the conduct that is proscribed may be struck down as violating due process of law. ${ }^{214}$ In Connally v. General Construction Company, ${ }^{215}$ the Supreme Court held that a law is unconstitutionally vague when a person of "common intelligence must necessarily guess at its meaning.,"216

Some scholars complain that the criminal prohibition of insider trading suffers from such vagueness. ${ }^{217}$ Indeed, Steven Cohen, founder of SAC Capital Advisors, LP, and the subject of a recent high-profile insider trading investigation, raised the issue in a recent deposition: "[i] t's my belief that the rule [against insider trading] is vague, and therefore, you can interpret the rule any way-you know, with-as a lawyer, you can probably interpret it in lots of different ways." 218 Professor Homer Kripke once noted that "fraud" in Rule 10b-5 has "come to mean anything that the SEC dislikes because by picking cases in which it can dramatically describe the facts, the SEC hopes that the facts will carry the law." ${ }^{, 219}$ This raises another concern. As Justice O'Connor explained in Kolender v. Lawson, ${ }^{220}$

the more important aspect of vagueness doctrine "is not actual notice, but the other principal element of the doctrine - the requirement that a legislature establish minimal guidelines to govern law enforcement." Where the legislature fails to provide such minimal guidelines, a criminal statute may permit "a standardless sweep [that] allows policemen, prosecutors, and juries to pursue their personal predilections. ${ }^{, 221}$

The point here is not to make the strong claim that the current insider trading enforcement regime should be struck down as unconstitutionally vague, but rather to suggest that its lack of statutory definition raises this specter and, at a minimum,

${ }^{213}$ U.S. CONST. art. I, $\S \S 9,10$.

${ }^{214}$ See, e.g., Papachristou v. City of Jacksonville, 405 U.S. 156, 162 (1972) (vagrancy ordinance found to be unconstitutionally vague).

215269 U.S. 385 (1926).

${ }^{216} \mathrm{Id}$. at 391 .

217 See, e.g., Homer Kripke, Manne's Insider Trading Thesis and Other Failures of Conservative Economics, 4 CATO J. 945, 949 (1985).

218 Greg Ferrell, SAC's Cohen May Face SEC Suit as Deposition Hurts Case, BLOOMBERG (Feb. 19, 2013, 5:00 PM), http://www.bloomberg.com/apps/news?pid=web port news\&tkr=MCD:US,PFE:US,WMT:US\&tkr2=PFE:US\&sid=atYHrhzi7XIQ, archived at $\mathrm{http}: / /$ perma.cc/CY9K-KLNW.

${ }^{219}$ Kripke, supra note 217 , at 949.

220461 U.S. 352 (1983).

${ }^{221} I d$. at 358 (quoting Smith v. Goguen, 415 U.S. 566, 574-75 (1974)). 
subjects it to moral scrutiny under the principle of legality. In light of this fact, the SEC should be careful not to rely on creative interpretations of "good faith" (e.g., enlisting the "spirit" of a law that has yet to be defined by statute and which is disputed by regulators and courts) to deprive insiders of the Trading Plan affirmative defense when they have otherwise complied with the letter of the rule.

\section{Cannot Solve Problem by Tweaking Current Rule}

To take stock, the SEC adopted Rule 10b5-1 in part to resolve the "use versus possession" debate and to bring clarity to the scope of insider trading liability. By adopting the "awareness" test, the SEC preserved much of its preferred knowing possession standard, but, in a nod to the decisions in Adler and Smith (and to the Section 10(b) requirement of scienter), the affirmative defense for Trading Plans was included in the rule as a compromise. In addition to the anticipated benefits, the introduction of Trading Plans had some unintended consequences: (1) certain aspects of Trading Plans allow the insider to more easily avoid detection and enforcement of illegal insider trading, and (2) the Plans created loopholes that arguably allow insiders to legally benefit from the use of material nonpublic information. And studies have confirmed that insiders who use Trading Plans are beating the market.

As the issue of Trading Plans continues to draw media attention, pressure mounts for the SEC to take action. But what action should be taken? Two options are before them. First, the SEC could attempt to address the issue through vigorous enforcement. Second, the SEC could seek to amend the law by statute or rule change. The recent announcements of investigations indicate the first option, enforcement, will be part of the strategy. But while aggressive enforcement can elevate the risks to would-be violators of the rules (perhaps compensating for the ways in which Trading Plans have made violations more difficult to detect and enforce), it cannot address the loopholes in the law. Moreover, the current state of uncertainty as to what conduct actually constitutes a violation of insider trading law generates moral and constitutional problems that would only be exasperated by aggressive enforcement of purported Trading Plan abuse as a common law crime. Consequently, it appears the second option, actual reform of the law of insider trading through statute or rule change, is the most appropriate and most likely path forward. Part VI outlines the reform advocated here. But before turning to this, it will be useful to explain why some solutions that have already been floated by scholars and market participants will not work.

\section{A. Problems with Some Suggested "Tweaks" to Rule 10b5-1}

The key to any successful reform of the existing 10b5-1 framework will be to maintain the rule's precarious compromise between the SEC's preferred "possession" test and the Section 10(b) requirement of scienter. The pressure for change focuses on the affirmative defense for Trading Plans, but it is precisely the availability of this defense that allowed the SEC to navigate the strait between the 
"possession" test and the "use" test adopted by the courts in Adler and Smith. In short, any limitations imposed on the availability of the Trading Plan affirmative defense must be careful not to undermine the already controversial claim by the SEC that the rule respects the Section 10(b) element of scienter.

A number of changes to the affirmative defense for Trading Plans have been suggested. These include requiring varying degrees of disclosure, limiting the ability of Plan users to terminate their Plans, precluding Plan transactions during companyimposed blackout periods, prohibiting multiple or overlapping Plans, and imposing a mandatory delay between establishment and trading under a Plan. Some of these suggestions are more helpful than others, but none of them, individually or taken together, will be sufficient to fully address the issue.

\section{Requiring Disclosure}

As noted above, there is currently no disclosure requirement for Trading Plans. Some have suggested the SEC adopt a rule requiring that firms and insiders disclose the establishment of Trading Plans, as well as any amendments, terminations, and transactions under them. ${ }^{222}$ The SEC has indicated that while it is open to a new rule requiring insiders to disclose Trading Plans ahead of trades, ${ }^{223}$ "there would need to be careful consideration of the costs and benefits." ${ }^{.224}$ A rule requiring disclosure of Trading Plans was proposed by the SEC in 2002 and was dropped. ${ }^{225}$ The 2002 proposal would have required companies to disclose the establishment of Trading Plans by directors or executive officers on a Form 8-K. Although the proposed rule would not have required disclosure of the specifics of the trades comprised by a newly established Plan, ${ }^{226}$ more detailed information would have been required with respect to Plan terminations or modifications. ${ }^{227}$ The stated rationale for the proposed rule change was that "current reports disclosing that a director or executive

${ }^{222}$ See, e.g., Letter from Jeff Mahoney to Mary Jo White, supra note 19; see also Eaglesham \& Barry, supra note 6 (noting that "Nejat Seyhun, a finance professor at the University of Michigan, believes the SEC should require companies to file plans with the agency and disclose details of them-including changes and cancellations--to investors").

${ }^{223}$ Pulliam \& Barry, Investors Call for More Disclosure, supra note 6 ("If [the SEC] heard significant calls for reproposal of [the pre-trade disclosure] requirement, the commission certainly could take it up again in the future ....").

${ }^{224}$ Pulliam \& Barry, Executives' Good Luck, supra note 6.

${ }^{225}$ Horwich, supra note 83, at 934-35 (discussing that although the SEC proposed that certain plans should be disclosed on Form 8-K, that proposal was "never formally withdrawn," and the disclosure proposal "appears to have been consigned to oblivion").

${ }^{226}$ Form 8-K Disclosure, supra note 164, at 19,921. Upon establishment of a Plan, the company would be required to report the director or executive officer's name and title, the date on which the Trading Plan was established, and a description of the Trading Plan including its duration, the aggregate number of securities to be purchased or sold, and the name of the agent with whom the Plan was set up. Id.

${ }^{227}$ Id . Upon termination or modification of a plan, the company would be required to disclose the date the termination or modification took place, and, in the case of a modification, its description in addition to the name and title of the insider. Id. 
officer has entered into, modified or terminated a Rule 10b5-1 [Plan] . . may provide investors with more extensive disclosure of potentially useful information as to management's views of the performance and prospects of the company. ${ }^{, 228}$ It is unclear why the SEC dropped this proposal to require disclosure, but it raises a number of concerns.

To begin, it is hard to reconcile the SEC's stated rationale for the disclosure requirement, offering "potentially useful information as to management's views of the performance and prospects of the company," 229 with the function of Trading Plans as an affirmative defense. Trading Plans only offer an affirmative defense to 10b-5 liability because the rulemakers recognized insiders will sometimes want to trade their company shares for reasons that have absolutely nothing to do with the future "performance and prospects" 330 of the company (e.g., diversification, or paying a child's college tuition). Moreover, an insider must be free of material nonpublic information when establishing the Plan. Thus, as one commenter on the rule put it, where the rule is being followed, "any subsequent transactions effected pursuant to a 10b5-1 plan or arrangement does not reflect the officer or director's view at that time regarding the business or prospects of the company."231 So for the disclosure requirement to make sense (i.e., for it to ensure the disclosure of "useful information" to investors), it must presume that insiders will violate the law on a regular basis. Such a disclosure requirement reduces to incoherence.

Indeed, some have expressed the concern that required Trading Plan disclosure would generate more confusion than clarity in the market. ${ }^{232}$ For example, disclosure of a large Plan sale by the CEO of a company may create the impression among investors that this reflects the CEO's assessment of the future prospects of the company. But, assuming the CEO is complying with the rule (and is not basing the decision to sell on material nonpublic information), this impression would be false. Nevertheless, the false impression could set off a selling spree that hurts other investors as well as the CEO ${ }^{233}$ Moreover, if the amount of stock to be bought or sold under the Trading Plan is relatively small in comparison with the insider's overall holdings, disclosure "may give the transaction(s) more visibility than warranted." ${ }^{234}$ Finally, given that advance disclosure of a Trading Plan sale (or purchase) could impact the price of the stock, investor expectations may be built around the Plan. If no trades end up being executed under the Plan (either because the undisclosed Plan transaction price is

${ }^{228}$ Id . at 19,916 .

${ }^{229}$ Form 8-K Disclosure, supra note 164 , at 19,925.

${ }^{230}$ See id. at 19,915.

${ }^{231}$ E-mail from Cary Klafter, Intel Corp., to Jonathan J. Katz, Sec'y, U.S. Sec. \& Exch. Comm'n (June 24, 2002, 2:51 PM), available at, http://www.sec.gov/rules/proposed/s70902 /srvirkar1.txt, archived at http://perma.cc/FFQ2-7UNB.

${ }^{232}$ See, e.g., Horwich, supra note 83, at 940 (suggesting required disclosure of 10b5-1 plans could have undesirable effects including artificial depression in stock prices).

${ }^{233} \mathrm{Id}$.

${ }^{234} \mathrm{Id}$. at 941. 
never hit, or because the Plan is modified or terminated before a transaction takes place), then disappointed investors may cry foul. ${ }^{235}$

But the above problems with requiring disclosure of Trading Plans presume that insiders are generally playing by the rules. There is little doubt that the current pressure to require advance disclosure of Trading Plans stems from overwhelming evidence of abuse and the thought that disclosure may have a mitigating effect. There is, however, an irony in this justification for disclosure. A recent study indicates that abnormal returns are significantly higher for transactions under voluntarily disclosed Trading Plans (particularly those that provide specific Plan details) than for those that are not disclosed. ${ }^{236}$ The explanation offered for this phenomenon is that "disclosure provides value to a 'hiding in plain sight' strategy because of its incremental legal protection," given that courts are likely to credit voluntary disclosure as evidence of legal compliance. ${ }^{237}$ Thus, it appears requiring disclosure would only be effective in compelling disclosure from those firms whose insiders are not abusing Trading plans.

\section{Restricting Plan Termination}

Many have suggested the best way to address the problem of selective Plan termination as a means for insiders to beat the market is to impose restrictions on Plan terminations. Professor Jesse Fried has suggested the rule be changed to require that insiders wait until they are unaware of any material nonpublic information before they are permitted to terminate their Plans. ${ }^{238}$ According to Fried, since most plans involve selling small amounts of shares on a regular basis, "there should be few liquidity or diversification costs to preventing insiders from canceling prearranged trades when they have information indicating that the trades would be unfavorable." ${ }^{239}$ Others have suggested that the rule be revised to simply lock insiders into Trading Plans for a fixed period (e.g., for six months or a year) before they can terminate, or even for the entire duration of the Plan (similar to restrictions on flexible health care spending accounts). ${ }^{240}$

\section{${ }^{235} I d$. at 942 .}

${ }^{236}$ See M. Todd Henderson et al., Hiding in Plain Sight: Can Disclosure Enhance Insiders' Trade Returns? 20 (Univ. of Chi. Law \& Econ., Working Paper No. 411, 2012), available at http://papers.ssrn.com/sol3/papers.cfm?abstract_id=1137928, archived at http://perma.cc/275J-S3MA.

${ }^{237}$ See id.

${ }^{238}$ Fried, supra note 179 , at 491.

${ }^{239} \mathrm{Id}$.

${ }^{240}$ See, e.g., Peter J. Henning, The Fine Line Between Legal, and Illegal, Insider Trading, N.Y. TIMES DEAL BOOK (Dec. 10, 2012, 3:17 PM), $\mathrm{http} / / /$ dealbook.nytimes.com/2012/12/10/the-fine-line-between-legal-and-illegal-insidertrading/?_r=0, archived at http://perma.cc/3ABK-33VW; Sougata Mukherjee, The Dangerous Game Corporate Executives Are Playing, TRIANGLE BIZBLOG (Dec. 11, 2012, 2:29 PM), http://www.bizjournals.com/triangle/blog/2012/12/the-dangerous-gamecorporate.html?page=all, archived at http://perma.cc/6MYF-CT25 ("[E]xecutives should 
There would, of course, be costs associated with such restrictions on the power to terminate. As explained above, any limitations placed on insiders' use of their company shares make them less valuable to the insider, and, consequently, more shares must be offered by the firm to achieve the same compensation. The restrictions would therefore come at a cost to the firm and its shareholders. Moreover, some have suggested that selective termination provides additional efficiency benefits by aligning the interests of management and shareholders because "enabling managers to abstain from selling on good news allows them to profit fully from the value that they create for shareholders." ${ }^{241}$ Others have suggested that allowing insiders to trade on material nonpublic information may help prevent accounting fraud because it offers insiders a means of separating their personal solvency from the company's reported performance. ${ }^{242}$ This argument would apply in the context of selective Plan terminations as well.

But economic considerations aside, the real problem with revising Rule 10b51 to restrict or preclude Plan terminations centers on the limits of the SEC's rulemaking authority. While the SEC has a history of expansive interpretations and aggressive enforcement of Section 10(b) and Rule 10b-5, since Chiarella, the courts have been adamant that the SEC's mandate is not so expansive as to outlaw all profits from material nonpublic information-only those that involve some form of fraudulent manipulation or deception in connection with the purchase or sale of a security. And, as explained above, selective termination does not appear to involve the purchase or sale of a security. One might respond, however, that the suggestion is not to make selective termination an insider trading violation, but rather it is to make refraining from termination (or refraining from termination based on material nonpublic information - depending on which suggested revision to the rule is followed) one more element that must be satisfied to avail oneself of the affirmative defense for Trading Plans. There are a number of points to be made here.

First, recall that the Trading Plan affirmative defense was only included in Rule 10b5-1 to soften the harshness of its awareness test; without the affirmative defense, the rule would have transformed insider trading into the practical equivalent of a strict liability offense. ${ }^{243}$ Without the affirmative defense, any trade made by an insider while merely aware of material nonpublic information would incur liability. Assume Rule 10b5-1(c) is revised to deny the affirmative defense for Plan trades when that Plan is terminated based on material nonpublic information. Now imagine the CEO of XYZ Inc. sets up a Trading Plan (while unaware of material nonpublic information) to liquidate some of her XYZ shares to pay for her daughter's college tuition. The Plan calls for the sale of 1,000 shares on the twenty-eighth of every month for the next six months. A week after the Plan is established, she learns of

not be allowed to terminate the plan before six months or 12 months").

${ }^{241}$ Fried, supra note 179 , at 491 n. 68 .

${ }^{242}$ See Robert E. Wagner, Gordon Gekko to the Rescue?: Insider Trading as a Tool to Combat Accounting Fraud, 79 U. CiN. L. REV. 973, 1000-05 (2011).

${ }^{243}$ Indeed, some have argued - even with the affirmative defense in place-to the extent that Rule 10b5-1 allows for liability without deception, it already imposes strict liability. See e.g., Swanson, supra note 47, at 151-52. 
negative material nonpublic information about XYZ Inc. She allows the first three trades under the Plan to be executed while she is aware of this information. She then learns that $\mathrm{XYZ}$ will disclose this negative information the day prior to her fourth scheduled trade under the Plan. She terminates the Plan on the basis of this material nonpublic information (recall, the SEC admits such a termination is legal and violates no laws). Under the proposed amendment to the rule, the result would be liability for three instances of illegal insider trading. The fact that the Plan was set up in good faith and without awareness of material nonpublic information would be irrelevant to the CEO's liability. Moreover, no proof that the first three transactions took place solely to pay for her daughter's college tuition would be available in her defense because she was aware of material nonpublic information when they occurred and the affirmative defense is unavailable. Such a result would be difficult to reconcile with the Supreme Court's recognition of the requirement of scienter for violations of $\S 10(\mathrm{~b})$, and with the holdings in Adler and Smith.

Second, if the rule were revised to preclude the Trading Plan affirmative defense where a Plan is terminated based on material nonpublic information, would the Rule 10b5-1 "awareness" test also apply to this determination? If so, then assume all the facts are the same as in the example above, but instead of terminating her Plan to avoid selling after the release of bad news, the CEO terminated the Plan solely because she just learned her daughter decided to ditch college and join the Air Force. Here, under this proposed amendment, because the CEO happened to be aware of material nonpublic information when she terminated the Plan (though she terminated for other reasons), she would nevertheless be liable for three counts of insider trading. Or imagine the result when an insider needs to, say, terminate a purchase order under a Plan to insure that she has adequate funds to pay for her husband's emergency heart surgery. Is she to be liable for any prior Plan trades made while she was aware of material nonpublic information? Again, such odd results cannot be reconciled with the requirement of fraudulent deception or manipulation required for Section 10(b) liability. But worse, there is absolutely nothing that is even conceivably wrongful with the insider's conduct in either of these two cases. Note also that amending the rule to simply preclude Plan terminations altogether (regardless of whether the insider is aware of material nonpublic information) would render the same problematic result whenever insiders have legitimate personal reasons for wishing to terminate a Plan. With any such restriction in place, insiders would risk incurring criminal liability for conduct that is in no way wrongful.

Finally, one might argue that, even if an absolute restriction on Plan terminations is not the answer, the rule should be modified to preclude companies and insiders from making frequent modifications or terminations of Plans. But it is hard to imagine how such a rule might look. The SEC's current interpretation of the rule that warns selective termination may call into question the good faith basis of the Plan is clearly designed to limit frequent terminations. But, in addition to lacking clarity, it has already been argued that this interpretation also leads to unacceptable results. ${ }^{244}$ 


\section{Problems for Other Proposed Reforms}

The following reforms to Rule 10b5-1 provide potential means to improving enforcement and detection of violations under the current rule. First, firms and insiders "should only be permitted . . . to buy or sell securities during companyadopted trading windows, which typically open after the announcement of the financial results from a recently completed fiscal quarter and close prior to the close of the next fiscal quarter." ${ }^{245}$ Second, as noted above, there is currently no rule about how long an insider must wait between establishing a Plan and trading under it. Some have proposed a mandatory delay between Plan establishment and the first trade under the Plan. ${ }^{246}$ Mandatory delays ranging from three ${ }^{247}$ to $\mathrm{six}^{248}$ months have been suggested. The purpose of these two suggested rule changes would be to make it difficult for insiders to disguise illegal trades based on material nonpublic information behind Plan Trades.

One problem with these suggestions is that they will significantly decrease insiders' flexibility in using Trading Plans for legitimate purposes. As explained above, any restriction on insiders' ability to trade their shares will make the company's shares less valuable to insiders, which will in turn present a cost to firms. Moreover, these suggestions will make it more difficult for insiders to avail themselves of the Trading Plan affirmative defense to effect legitimate trades. Imagine an insider has a stock option that will vest in one month and knows that she will need to execute the option at that time to make a balloon payment on her house. This insider is not aware of material nonpublic information at the time, but she knows she may be aware of such information in one month. She would like to establish a Trading Plan to execute the options when they vest in one month, but she would be prevented from doing so if the rule were changed to, for instance, impose a mandatory three- or six-month delay. With such restrictions on the use of Trading Plans in place, the insider will have to wait the month. If she becomes aware of material nonpublic information when her options vest, she will be forced to choose between executing the options and incurring insider trading liability or foreclosure on her home. Again, it is difficult to see how the requirement of scienter under Section 10(b) could be reconciled with this harsh result. Thus, any benefits of these suggested reforms in terms of deterring illegal insider trading must be balanced against the risk that their potentially harsh application may not survive judicial scrutiny.

Another suggested change has been to preclude multiple or overlapping Trading Plans. ${ }^{249}$ This change would be directed at preventing the practice of

${ }^{245}$ Letter from Jeff Mahoney to Mary Jo White, supra note 19.

${ }^{246}$ See id.; Mukherjee, supra note 240.

${ }^{247}$ See, e.g., Letter from Jeff Mahoney to Mary Jo White, supra note 19.

248 See, e.g., Mukherjee, supra note 240.

${ }^{249}$ See, e.g., Letter from Jeff Mahoney to Mary Jo White, supra note 19. 
hedging one Trading Plan with another. ${ }^{250}$ Since such hedging is already prohibited by the rule, the change, like the last two, would amount to nothing more than an attempt to make it more difficult to violate the law. And, also like the last two proposed changes, any benefits in the form of enhanced detection and enforcement of illegal conduct will have to be weighed against the decrease in flexibility to insiders and firms in using Trading Plans for legitimate purposes. There are a number of legitimate reasons for having multiple overlapping Plans. For example, some have suggested that any Plan with a duration less than twelve months is "aggressive." ${ }^{251}$ Thus, if the typical Plan is one year or longer, it only stands to reason that, as more near-term investment needs arise, an insider may wish to set up a second consistent Plan to address those needs without having to terminate an existing Plan, particularly if termination is likely to raise suspicion among regulators. The limitation would become more suffocating still to insiders if it were paired with restrictions on the termination of Plans. If an insider has no means of terminating an existing Plan, and cannot establish an overlapping Plan, the insider is out of luck in the event of a change in investment strategy, or worse, in a personal or family emergency. Again, such restrictions may force the insider to trade outside of a Plan, risking harsh results under the Rule 10b5-1 awareness test.

\section{Need for Regime Change}

Again, Rule 10b5-1 and its affirmative defense for Trading Plans reflects an attempt by the SEC to resolve its differences with the federal courts in the "use versus possession" debate. The rule was designed to give the SEC what it wanted (an awareness test that would ease the burden of enforcement), while appeasing the courts' demand for scienter (with the affirmative defense). In addition, Trading Plans would offer insiders more flexibility and certainty in legitimate trading. Since its adoption, however, the rule has had unintended and unwanted consequences. A number of reforms have been suggested by scholars and marketed participants, but each of these reforms would likely upset this delicate compromise. This may explain the SEC's demonstrated hesitancy to embrace significant reform of Rule 10b5-1 to date. Nevertheless, the media attention and consequent public pressure for Trading Plan reform has virtually assured that some rule changes are on the horizon. As one fund manager put it, "[I] would be shocked if the SEC" does not act. ${ }^{252}$ The takeaway is that if there is to be enduring reform to the current Trading Plan regime, it cannot be achieved by merely tweaking or supplementing the current language of Rule $10 \mathrm{~b} 5-1$. An entirely new regime must be put in place.

${ }^{250}$ See Melbinger, supra note 132.

${ }^{251}$ Ed Welsch, Trading Plans Offer a Good Clue to Sell, WaLl St. J. (Apr. 9, 2008, 12:01 AM), http://www.wsj.com/articles/SB120770890145300645, archived at http://perma.cc/Z3BL-QLXM (considering "any plan of less than 12 months in length an aggressive use" of Rule 10b5-1(c)).

${ }^{252}$ Eaglesham \& Barry, supra note 6. 


\section{FROM CRISIS TO RATIONAL REFORM}

One's choice of solutions to the Trading Plan problem will depend on where one locates the crisis. Is the principal concern that Trading Plans have exposed a gap in enforcement coverage resulting in some insiders being permitted to profit by trading on their company's material nonpublic information? Or is the controversy over Trading Plans symptomatic of a broader and deeper concern: that the current enforcement coverage is unprinicipled, undefined, and therefore irrational and inefficient. Though the media and SEC focus has been on the ability of insiders to exploit Trading Plans to beat the market, no one has stopped to ask why-at least in the context of Trading Plan transactions authorized by the insider's firm-this is a problem. It is only a problem if such trading is harmful or unfair. So far it has simply been assumed that such Plan trading is harmful and unfair. But an irony in the SEC's introduction of Trading Plans has been that their efficient use by insiders and firms as a means of compensation has exposed a discrete sphere of insider trading that is economically harmless and morally unproblematic. Thus, rather than serve to increase the enforcement power of the SEC, the introduction of Trading Plans may have cleared the path to rational reform in insider trading law through liberalization and decriminalization. Such a proposed reform is motivated and outlined in what follows.

As noted above, Section 10(b) insider trading liability typically falls under one of two theories: the classical theory and the misappropriation theory. This Author has argued elsewhere ${ }^{253}$ that, at least for purposes of moral and economic evaluation, it makes sense to refine the distinction still further by dividing the classical theory into two more categories based on whether the insider has undertaken some express or tacit commitment not to trade on her company's material nonpublic information:

Issuer-Proscribed Insider Trading: Insider trades on material nonpublic information where the insider has promised-or otherwise undertaken pursuant to company policy [express or implied] - not to trade on such information. ${ }^{254}$

Issuer-Licensed Insider Trading: Insider trades on material nonpublic information [with the firm's approval] . . . (It is presumed that the issuer's policy allowing insider trading is disclosed to the investing public. $)^{255}$

Assuming an imaginary legal regime that does not already prohibit insider trading, ${ }^{256}$ this Author has argued a rigorous moral and economic analysis reflects that, while both trading under the misappropriation theory and issuer-proscribed

${ }^{253}$ See Anderson, supra note 25, at 18.

${ }^{254} \mathrm{Id}$. at 27 (referring to it as "promissory insider trading").

${ }^{255} \mathrm{Id}$. at 28 (referring to it as "nonpromissory insider trading").

${ }^{256}$ This is done to insure the morality of insider trading can be tested independent of any social expectations arising solely from the fact that certain conduct is illegal. Id. at 27 . 
insider trading are immoral and economically inefficient, issuer-licensed insider trading is morally permissible and harmless from the standpoint of economic efficiency. ${ }^{257}$ If this conclusion is correct, then not only is liability for issuer-licensed insider trading unnecessary, it is unfair and unjust. Nevertheless, there remains the difficulty of tailoring an enforcement regime that can efficiently distinguish between these permissible and impermissible forms of insider trading. A modified form of the 10b5-1 Trading Plan might serve this purpose.

Recall that firms typically anticipate and negotiate the ability of employees to use Trading Plans to profit from the use of material nonpublic information. As noted in Part V.A.1, firms relying on market-beating Plan trading as part of their compensation packages typically disclose the establishment of Trading Plans in their regulatory filings. ${ }^{258}$ Such permission and disclosure begins to resemble the use of Trading Plans as a limited form of issuer-licensed insider trading. This Article argues, such use of Trading Plans should not be regarded as a source of concern, but rather openly embraced and expanded by the law. The liberalizing move of openly permitting issuer-licensed insider trading as regulated through a modified Trading Plan model would result in a more rational, efficient, and just insider trading enforcement regime. The proposed reform is outlined first, and then it is defended.

\section{A. Proposed Regime Change}

The reform proposed here would modify Trading Plans (henceforth "Modified Trading Plans" or "Modified Plans") to permit insiders complete freedom to actively trade (or abstain from trading) based on their firm's material nonpublic information, so long as (1) the insider's Modified Plan is approved by the firm and (2) the authorizing firm has disclosed to the investing public that it allows its insiders to trade based on the firm's material nonpublic information through Modified Plans.

By requiring the firm to authorize each Modified Plan, the new rule would ensure only issuer-licensed insider trading would be granted safe harbor. Issuerproscribed and misappropriation trading would remain subject to Section 10(b) and Rule 10b-5 liability. Authorization of these Modified Plans could be handled directly by the firm's general counsel or through its compliance department. Most firms already have some form of procedure in place for authorizing Trading Plans under the current regime, and this new rule would not require any significant change in their practices.

Firms allowing insiders to trade pursuant to Modified Trading Plans under the liberal regime proposed here must disclose this practice. But the firm's Modified

${ }^{257}$ Anderson, supra note 25, at 27-54; see also, John P. Anderson, What's the Harm in Issuer-Licensed Insider Trading?, 69 U. MIAMI L. REV. (forthcoming Spring 2015) (arguing that issuer-licensed insider trading is morally permissible, and, inter alia, criticizing Professor William Wang's use of the "Law of Conservation of Securities" to support his claim that such trading results in wrongful harm). Arguments for the moral permissibility of issuer-licensed insider trading are also summarized below. See discussion infra Parts VI.B., VI.C.

${ }^{258}$ See Henderson et al., supra note 236, at 20. 
Trading Plan disclosure requirement will end there. Firms will neither be required to disclose ex ante the contents of its insiders Modified Plans, nor when they are established, altered, or terminated. Nevertheless, this minimal disclosure requirement will be sufficient to place the investing public on notice that the firm allows its employees to trade based on the firm's material nonpublic information. ${ }^{259}$ It will, therefore, allow investors to make an informed decision about whether to trade in the firm's shares. ${ }^{260}$ At the same time, this minimal disclosure requirement will avoid the problems of front-running and of potentially misleading the public that would likely arise if more detailed disclosure were required. ${ }^{261}$

Though firms should not be required to disclose individual Modified Trading Plans or their contents ex ante, insofar as the ability to use these Modified Plans will be bargained for by firms as part of their compensation for employees, firms should disclose this compensation ex post. Firms should therefore disclose their insiders' Modified Trading Plan profits in some summary form. ${ }^{262}$

Finally, the Adler use test (supplemented by the strong presumption of use where there is knowing possession of material nonpublic information ${ }^{263}$ ) should replace the current Rule 10b5-1 awareness test in determining insider trading liability for all trades that occur outside Modified Trading Plans. This will have the effect of making Modified Trading Plans a nonexclusive safe harbor from Section 10(b) and Rule 10b-5 insider trading liability. As explained above, despite the SEC's stated aspiration of improving "clarity and certainty" in insider trading law with the introduction of its awareness standard, ${ }^{264}$ it has added to the confusion. At least in the context of insider trading, the SEC simply invented the term "awareness." This has left many confused as to whether "awareness" differs from "knowing possession," and if so, how. ${ }^{265}$ Moreover, the "awareness" test must be applied in

259 See, e.g., Saikrishna Prakash, Our Dysfunctional Insider Trading Regime, 99 COLUM. L. REv. 1491, 1515-20 (1999) (arguing that disclosure of general intent to allow trading on the firm's material nonpublic is sufficient to avoid deception).

${ }^{260}$ See, e.g., Anderson, supra note 25, at 36-40; Prakash, supra note 259, at 1515-20.

${ }^{261}$ See supra Part V.A.1.

${ }^{262}$ Professor Henderson makes a similar suggestion. Henderson, supra note 125 , at $550-51$.

${ }^{263}$ Of course some courts may be unwilling to recognize such a presumption in the criminal context. See, e.g., United States v. Smith, 155 F.3d 1051, 1069 (9th Cir. 1998) (suggesting such a burden shift against the defendant in the criminal prosecution would suffer constitutional infirmities). However, as Professor Donald C. Langevoort points out, some of the practical burden of proof under the use test (even absent an Adler-style presumption) "is ameliorated by the fact that" subjective intent for insider trading "can be proven circumstantially," allowing fact-finders to "draw inferences about causation from the surrounding facts." Donald C. Langevoort, What Were They Thinking? Insider Trading and the Scienter Requirement, in RESEARCH HANDBOOK ON INSIDER TRADING 52, 54 (Stephen M. Bainbridge ed., 2013).

${ }^{264}$ August 2000 Exchange Act Release, supra note 10, at 51,727.

${ }^{265}$ See id. at 51,727 n.105 (noting some commenters on the proposed rule "stated that 'aware' was an unclear term that may be interpreted to mean something less than 'knowing possession"'); see also Swanson, supra note 47, at 206 ("Although it is not certain that Rule 
tandem with the Rule 10b5-1 affirmative defenses, which are designed to prevent any "overbroad" applications: ${ }^{266}$ But, as noted above, SEC interpretations of the "good-faith" restriction on the availability of the affirmative defenses under the Rule leave insiders guessing as to whether their compliance with the letter of the law will not still leave them exposed to civil and criminal liability. Where the "awareness" test leaves room for civil or criminal liability without scienter, the requirement of deliberate use would protect insiders from being found criminally liable for morally innocent conduct. Thus, adopting the Adler use test appears to be the best way to bring coherence to the existing enforcement regime by respecting the Section 10(b) requirement of scienter without undermining enforcement.

Having laid out the basic outline for the proposed reform, the next sections evaluate the comparative advantages of the proposed reform.

\section{B. No Economic Harm and Clear Economic Benefits}

The scholarly debate concerning the overall economic impact of insider trading on individual traders and the market is vigorous and ongoing. ${ }^{267}$ The point that needs to be emphasized here, however, is that the best arguments for economic harms and inefficiencies resulting from insider trading would not apply to the issuer-licensed insider trading permitted through the proposed Modified Trading Plans. Instead, there would be a number of obvious economic advantages that could be gained by legalizing issuer-licensed insider trading through Modified Trading Plans.

The impact of insider trading on the counterparties to insider transactions is disputed. ${ }^{268}$ The argument that the counterparty is harmed by insider trading typically turns on the seemingly straightforward claim that, if the counterparty knew what the insider knows, then she would not have sold at the price she did. ${ }^{269}$ The counterparty, therefore, loses the difference between the transaction price and the price the stock would trade at with the release of the insider's material nonpublic information. But, as many commentators have recognized (most notably Professor Henry Manne), the relevant issue is not what the counterparty would have done if she had the same information as the insider, but whether the counterparty would have behaved any differently had the insider never traded at all. ${ }^{270}$ In short, an

10b5-1's awareness standard matches the SEC's knowing possession position, the two doctrines certainly could be the same.").

${ }^{266}$ August 2000 Exchange Act Release, supra note 10, at 51,727.

${ }^{267}$ See Anderson, supra note 25, at 7-17.

${ }^{268}$ See id. at 7.

${ }^{269}$ See, e.g., In re Cady, Roberts \& Co., 40 S.E.C. 907, 914 (1961) ("If purchasers on an exchange had available material information known by a selling insider, we may assume that their investment judgment would be affected and their decision whether to buy might accordingly be modified. Consequently, any sales by the insider must await disclosure of the information.").

${ }^{270}$ See, e.g., Manne, supra note 180, at 933-34; see also William J. Carney, Signaling and Causation in Insider Trading, 36 CATH. U. L. REV. 863, 870 (1987); Henry G. Manne, Insider Trading and the Law Professors, 23 VAND. L. REV. 547, 552 (1970). 
insider's trading only inflicts an economic harm on the counterparty if, but for the insider's trading, the counterparty would not have traded. ${ }^{271}$ This is almost never the case where trades are made on the open market. Of course, sufficient insider entry into the market for a stock may move its price. Such price movement may, in turn, lead speculators (who typically trade based on price) to trade in the relevant stock. ${ }^{272}$ But this does not result in an obvious net economic harm to those who trade in the stock while insiders affect its price. This is because it is likely there will be an equal number of short-swing investors trading on the same side as the insiders as there will be trading against them. ${ }^{273}$

But even if one rejects this logic and remains convinced that someone must be paying for the insider's risk-free profits-it must be the firm's shareholders (both present and future) - this is not a problem for issuer-licensed insider trading. As noted in Part III.C, where firms expressly or tacitly approve of their insiders' trading on material nonpublic information, they offset the insiders' gains with a reduction in other forms of compensation. Consequently, as Professor Henderson explains, there is no economic harm: "Current shareholders should be happy with a deal that pays managers in part out of the hide of future shareholders," and ultimately the firm will "internalize any costs arising from this payment scheme, since future shareholders should take this into account when deciding whether and at what price to buy shares." 274 Moreover, since most shareholders are diversified, those "who have to pay less for executive talent in one firm have to pay more in another firm, simply by virtue of when they enter the shareholder pool."275 Thus, "[o]n average, shareholders should be indifferent.",276

Another economic harm commonly attributed to insider trading is that it forces market makers to increase the spread between their bid and ask prices to protect against adverse selection by insider trading. ${ }^{277}$ This increase in the bid-ask spread can inflict an economic harm on firms by raising their cost of capital. But where such insider trading is issuer-licensed, the firms willingly internalize this cost, again, presumably because this cost is outweighed by corresponding benefits to the firm. ${ }^{278}$ It is important to emphasize, however, that the result is not economically harmless when firm members engage in issuer-proscribed insider trading (i.e., in breach of an express or implied commitment to the firm not to trade). This is because firms may not recover the costs of issuer-proscribed insider trading through reduced direct compensation. Consequently, such trading may hurt both current and future shareholders of the firm.

271 See, e.g., HENRY G. MANNE, INSIDER TRADING AND THE StOCK MARKET 93 (1966).

${ }^{272}$ Cf. id. at 94-96 (describing speculators).

${ }^{273}$ See Anderson, supra note 25, at 12.

${ }^{274}$ Henderson, supra note 125, at 507-08.

${ }^{275} \mathrm{Id}$. at $543-44$.

${ }^{276} \mathrm{Id}$.

277 See, e.g., Stanislav Dolgopolov, Insider Trading and the Bid-Ask Spread: A Critical Evaluation of Adverse Selection in Market Making, 33 CAP. U. L. REV. 83, 105 (2004).

${ }^{278}$ See Anderson, supra note 25, at 30-31; Henderson, supra note 125, at 544. 
Insider trading incentivizes entrepreneurialism by allowing insiders to profit from the good news they generate for the firm, which is often regarded as a virtue. ${ }^{279}$ But the countervailing concern is that the ability to trade on material nonpublic information can just as easily create perverse incentives for firm employees to create bad news. ${ }^{280}$ Insider traders profit from volatility of any kind-good or bad. But there are a number of considerations that would weaken any incentive for insiders to try to create bad news. For example, such conduct would likely affect their compensation and put their jobs in jeopardy. ${ }^{281}$ But, in any event, under the reform proposed here, only trading pursuant to a Modified Trading Plan that is preapproved by the firm would be permitted. All other forms of insider trading currently proscribed by law would remain illegal. Consequently, firms would be free to reject any proposed short selling by employees. Indeed the firm will be free to tailor its employee insider trading practices however it chooses. They would be free to reject any trading suspected as harmful to the firm. For example, a firm that otherwise allows Modified Trading Plan transactions could impose a blackout during a takeover negotiation.

One of the more significant costs to firms from insider trading is that of compliance and litigation. But it should be easy to see how permitting issuerlicensed trading through Modified Trading Plans should significantly reduce such costs. It was noted above that $10 \mathrm{~b} 5-1$ Trading Plans have already significantly reduced compliance costs by offering firms an express rule-based procedure (however flawed) for allowing insiders to trade while minimizing risk of liability. In addition, the availability of the affirmative defense for Trading Plans helps firms discourage civil and criminal insider-trading-related actions against the firm and its insiders. Liberalizing the rule and expanding the safe harbor for insiders to trade would only amplify these advantages to firms.

\section{Issuer-Licensed Insider Trading Is Morally Permissible}

But economic considerations aside, one might still object that all insider trading based on material nonpublic information should continue to be proscribed because it is inherently dishonest, deceptive, and unfair. While there is truth to this claim when directed to issuer-proscribed insider trading and trading under the misappropriation theory, ${ }^{282}$ there is no moral basis for proscribing the issuer-licensed insider trading that would be permitted under this proposal. Both issuer-proscribed insider trading and trading under the misappropriation theory involve dishonesty and deception, the former by breaching a commitment to the firm ${ }^{283}$ and the latter by

${ }^{279}$ See, e.g., Henry G. Manne, Entrepreneurship, Compensation, and the Corporation, 14 Q.J. AUSTRIAN ECON. 3, 14 (2011).

${ }^{280}$ See, e.g., Saul Levmore, Securities and Secrets: Insider Trading and the Law of Contracts, 68 VA. L. REV. 117, 149 (1982); Morris Mendelson, Book Review, The Economics of Insider Trading Reconsidered, 117 U. PA. L. REV. 470, 489-90 (1969).

281 See Anderson, supra note 25, at 13-14; see also MANNE, supra note 271, at 150.

282 See Anderson, supra note 25, at 36.

${ }^{283}$ See id. at $18-19$. 
breaching a commitment to the source of the information. ${ }^{284}$ Aside from whatever inherent wrong there may be in breaking promises generally, the issue-proscribed trader and the misappropriator impose an identifiable harm on the firm and the source respectively by undermining the value of the commitment that was sought. ${ }^{285}$ In addition, one could argue the issuer-proscribed insider trader enjoys an unfair advantage over other market participants. This is because the other market participants reasonably operate under the presumption that no insider trading based on material nonpublic information occurs by insiders of firms that do not permit such trading. Market participants may price and trade in that company's shares with this presumption in mind. When the issuer-proscribed insider trades on material nonpublic information, she takes unfair advantage of market expectations built around this understanding. ${ }^{286}$

But notice, the issuer-licensed insider who trades pursuant to the Modified Trading Plans proposed here is neither dishonest nor unfair. There is no dishonesty or deception vis-à-vis the firm because the insider has candidly negotiated her ability to trade on material nonpublic information as part of her compensation, and the firm must approve each Modified Plan trade before it is made. ${ }^{287}$ And there is no deception or unfairness vis-à-vis other market participants because the Modified Trading Plan disclosure requirement gives the market notice that insiders may trade based on the firm's material nonpublic information. ${ }^{288}$ Market participants may, therefore, demand a correspondingly lower price for the stock or refuse to trade in the firm's shares altogether-the choice is theirs. ${ }^{289}$ By respecting other market participants with this disclosure, the issuer-licensed insider trader who trades pursuant to a Modified Plan does not take advantage. In the words of philosopher Immanuel Kant, market participants are thereby respected as "ends in themselves" and not as mere means to the trader's ends. ${ }^{290}$

\section{The Proposed Reform Is Consistent with Existing Statutory Authority}

The SEC's rulemaking authority can effect entirely the reforms proposed here because they are consistent with statutory authority and current Supreme Court precedent. ${ }^{291}$ Recall that Section $10(\mathrm{~b})$ insider trading liability must capture some

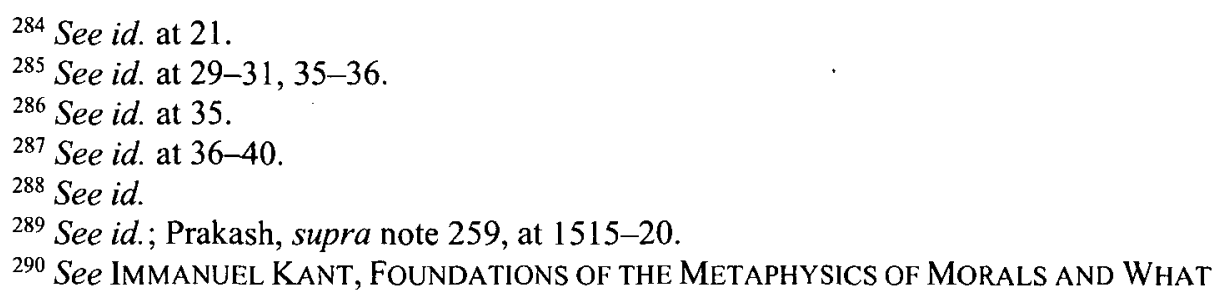
Is ENLIGHTENMENT? 50 (Lewis White Beck trans., 2d ed. 1990); Anderson, supra note 25, at $36-40$.

${ }^{291}$ This is important because Congress has repeatedly demonstrated an unwillingness to define insider trading or its elements by statute. See, e.g., BAINBRIDGE, supra note 27, at 28-29. 
fraudulent deception on the part of the trader. ${ }^{292}$ Under the misappropriation theory as articulated in $O^{\prime}$ Hagan, the fraud is on the source of the information. ${ }^{293}$ Under the classical theory as articulated in Chiarella, the fraud is on the shareholder (or future shareholder). ${ }^{294}$ In the case of misappropriation, the deception lies in the failure to disclose the intention to trade to the source of the information. The deception being that, without such disclosure, the information is obtained under false pretenses. ${ }^{295}$ In the case of the classical insider, the deception also lies in the failure to disclose, but it is typically thought the required disclosure pertains to the underlying information, not the intent to trade. There is, however, no obvious reason for this asymmetry, particularly in light of the Supreme Court's claim in O'Hagan that the two theories are intended to complement one another in capturing the entire universe of the same deceptive conduct (the one when it is perpetrated by insiders and the other when it is perpetrated by outsiders) ${ }^{296}$ If the misappropriation model is followed, disclosure to the investing public that a firm will allow its insiders to trade based on material nonpublic information through Modified Trading Plans when it is in the interest of the firm should be adequate to put current and future shareholders on notice and allow the firm to avoid Section 10(b) deception under $O^{\prime}$ Hagan. Market participants can then choose to buy, hold, or sell shares in the firm informed by this information. And, no doubt, the firm's decision whether to continue to offer compensation through Modified Trading Plans will in turn be informed by the marketplace's reaction to its policy. ${ }^{297}$

The claim that firms' advance disclosure of intent to allow insiders to trade on their material nonpublic information should be sufficient disclosure to avoid Section 10(b) deception is not so outrageous as to have never been advanced before. For example, Professor Henderson argues there is "arguably no deception [under O'Hagan] in a case in which the firm discloses that insiders are likely to be trading based on informational advantages." ${ }^{208}$ Henderson adds the disclose or abstain requirement may be satisfied by the "generic disclosure about insider propensity to trade on inside information," which is likely to "achieve the same kind of price adjustment and cost internalization" as full disclosure of the actual facts "on average. $" 299$

Moreover, the sufficiency of notice of intent to trade on material nonpublic information is reinforced by the Supreme Court's emphasis in Chiarella that Section 10(b) does not ensure parity of information; it only protects against information advantages acquired by deception. ${ }^{300}$ Accordingly, allowing insiders to trade based on material nonpublic information according to Modified Trading Plans, as

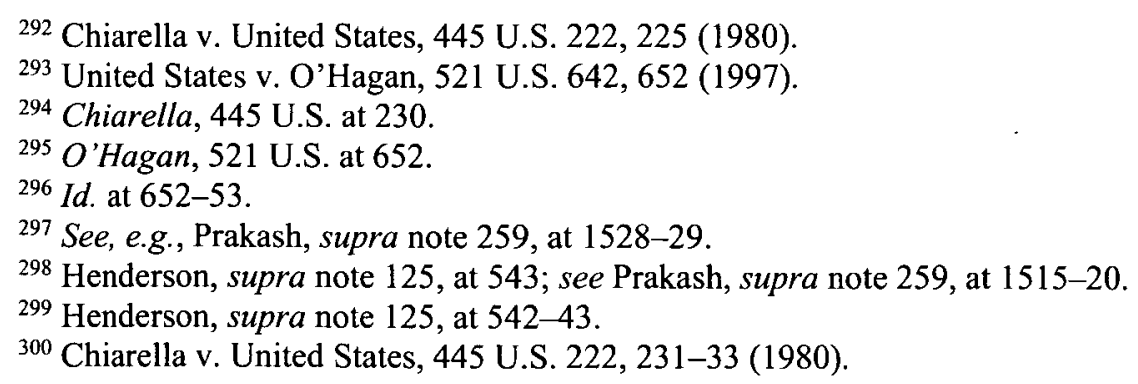


proposed here, would simply add one more category of such trading to those already permitted, such as those who trade based on information acquired by accident or eavesdropping, ${ }^{301}$ those who trade where the tipper does not benefit, ${ }^{302}$ those who trade where intent to trade is announced to the source under the misappropriation theory, ${ }^{303}$ and those who engage in insider abstinence (as discussed in detail above).

Finally, some have argued the real rationale behind the prohibition of insider trading is less about fraud than it is about property rights to information ${ }^{304}$ or simply wrongful conduct. ${ }^{305}$ If this is true, the nonexclusive safe harbor for insider trading pursuant to Modified Trading Plans proposed here would be perfectly consistent. After all, such trading would not be permitted unless first approved by the proprietors of the information (the firm) and such issuer-licensed trading would not be wrongful.

\section{E. Existing Enforcement Regime Sufficient to Address Timing of Disclosure}

The reform proposed here does nothing to specifically address the issue of timing disclosures around Plan trades. ${ }^{306}$ The availability of firm-sanctioned Modified Trading Plans would, however, significantly reduce incentives for insiders to time disclosures (or to accelerate or delay the making of news) to advantage trades. After all, Modified Trading Plans could be established at any time to take advantage of news in its natural course. And, in any event, as indicated above, the existing regime seems adequate to address any harm to the firm or investors from improper timing of disclosures. For example, the existing regime already has the ability to find liability for false disclosures, or disclosures that were improperly omitted from required filings. ${ }^{307}$ This leaves only harmless acceleration or delay of disclosure that is otherwise permitted by disclosure rules. The apparent lack of harm and extreme difficulty of proof relating to such tinkering with the timing of disclosure or news to benefit Plan trades (along with the reduced incentive for such timing decisions under a Modified Trading Plan regime) suggest that direct regulation would do more harm than good by placing otherwise innocent timing decisions under regulatory scrutiny.

In sum, consider some obvious advantages of adopting the reforms outlined above over preserving the existing regime. The proposed reforms offer a coherent approach to insider trading enforcement-whether it is justified in terms of fraud,

301 See, e.g., SEC v. Switzer, 590 F. Supp. 756, 766 (W.D. Okla. 1984).

${ }^{302}$ See, e.g., SEC v. Maxwell, 341 F. Supp. 2d 941,948 (S.D. Ohio 2004).

${ }^{303}$ See, e.g., United States v. O'Hagan, 521 U.S. 642, 652 (1997).

${ }^{304}$ See, e.g., STEPHEN M. BAINBRIDGE, CORPORATION LAW AND ECONOMICS 598-605

(2002); Frank H. Easterbrook \& Daniel R. Fischel, The Economic Structure of CORPORATE LAW 266-70 (1991).

${ }^{305}$ See, e.g., Donna M. Nagy, Insider Trading and the Gradual Demise of Fiduciary Principles, 94 lowa L. REV. 1315, 1377 (2009).

${ }^{306}$ See discussion supra Part IV.B.1.

${ }^{307}$ For example, there are antifraud provisions in the Securities Act, at 15 U.S.C. $\S 77 q$ (2013), and the Exchange Act, at 15 U.S.C. $\S 78 j(b)$ (2013). 
wrongful conduct, or property rights. Permissible and impermissible insider trading can now be more clearly delineated. The conduct that is proscribed can actually be enforced with justifiable vigor because it only captures conduct that is in fact deceitful, unfair, and harmful. By contrast, in addition to allowing for the prosecution of insider trading absent a showing of scienter, the existing regime punishes issuer-licensed insider trading (which is not deceitful, unfair, or harmful) with massive fines and stiff prison sentences. Litigation costs to firms defending against insider trading claims will be reduced under the proposed reform. Arguably no statutory revisions would be necessary for its implementation; the change could be effected entirely through rulemaking. It is true the SEC would have to eat some humble pie in admitting, as it turns out, not all insider trading based on material nonpublic information is wrong and harmful (something they have been unwilling to admit so far), but the benefit of a more rational and just enforcement regime should be worth it.

\section{CONCLUSION}

The SEC is poised to take action in the face of compelling evidence that corporate insiders are availing themselves of rule-sanctioned Trading Plans to beat the market. Since the market advantage insiders have enjoyed from Plan trading can be traced to loopholes in the current regulatory scheme, increased enforcement of the existing rules cannot solve the problem. But simply tweaking the existing rule structure to close these loopholes would not work either. This is because the SEC adopted the current rule as a part of a delicate compromise with the courts in the "use versus possession" debate over the appropriate test of scienter for insider trading liability. The current rule reflects the SEC's preferred test (mere "awareness"), but it provides for Trading Plans as an affirmative defense in order to pass judicial scrutiny. Any attempt to simply close the loopholes in Trading Plans while maintaining the awareness test would upset this delicate compromise. Thus, only a comprehensive change to the current insider trading enforcement regime can address the issue. The SEC should confront this crisis by adopting much-needed reform.

The reform proposed here begins with the recognition that Plan trading is generally done with the firm's awareness and consent. Such trading is, therefore, a form of issuer-licensed insider trading. Since there are strong arguments that there is no moral wrong or economic harm done by issuer-licensed insider trading, the regulatory regime should openly embrace it as a permissible form of compensation through firm-sanctioned Modified Trading Plans, so long as there is adequate disclosure. Though such liberalization would represent a radical departure from the current enforcement regime, it would be within the SEC's rulemaking authority and would be consistent with Supreme Court precedent. Most importantly, it would dramatically improve the current enforcement regime in terms of justice, clarity, efficiency, and coherence.

The proposed liberalization of insider trading law would be limited strictly to issuer-licensed insider trading through Modified Trading Plans; it would not protect 
insiders who trade by deception. Moreover, insider profits from Modified Trading Plan transactions should be disclosed to the investing public.

It is sometimes said there is nothing like a good crisis for effecting much needed change. The current media attention and public scrutiny over corporate insiders' exploitation of rule-sanction Trading Plans may be just the crisis to spur the SEC to adopt a more rational and just approach to insider trading enforcement. The outline for such reform has been proposed herein. 